\title{
STED Super-Resolution Imaging with an Advanced Organic Fluorescent Probe: Visualizing the Cellular Lipid Droplets at the Unprecedented Nanoscale Resolution
}

Ri Zhou, Chenguang Wang, * Xishuang Liang, Fangmeng Liu, Xu Yan, Xiaomin Liu, Peng Sun, Hongyu Zhang, Yue Wang, and Geyu Lu*

\section{Chemical Synthesis}

General. ${ }^{1} \mathrm{H}$ and ${ }^{13} \mathrm{C}\left\{{ }^{1} \mathrm{H}\right\}$ NMR spectra were recorded with a Zhongke-Niujin AS 400 (400 MHz for ${ }^{1} \mathrm{H}$ and $100 \mathrm{MHz}$ for ${ }^{13} \mathrm{C}$ ) or a Bruker AVANCEIII 500 spectrometer $(500 \mathrm{MHz}$ for ${ }^{1} \mathrm{H}$ and $126 \mathrm{MHz}$ for ${ }^{13} \mathrm{C}$ ) in $\mathrm{CDCl}_{3}$ or DMSO- $d_{6}$. The chemical shifts in ${ }^{1} \mathrm{H} \mathrm{NMR}$ and ${ }^{13} \mathrm{C}$ NMR spectra are reported in $\delta$ ppm using tetramethylsilane as an internal standard. The mass spectrometry was performed on a Bruker Autoflex TOF/TOF using trans-2-[3-(4-tertbutylphenyl)-2-methyl-2-propenylidence] malononitrile as a matrix. All reactions were performed under a $\mathrm{N}_{2}$ atmosphere, unless otherwise stated. Commercially available solvents and reagents were used without further purification unless otherwise mentioned.

2-(4-(Dimethylamino)phenyl)acetonitrile. To a solution of 2-(4-aminophenyl) acetonitrile $(2.00 \mathrm{~g}, 15.0 \mathrm{mmol})$ in dry DMF $(30 \mathrm{~mL})$ was added $\mathrm{K}_{2} \mathrm{CO}_{3}(4.50 \mathrm{~g}, 30.0 \mathrm{mmol})$ and iodomethane $(12.8 \mathrm{~g}, 90.0 \mathrm{mmol})$, and the resulting mixture was stirred at $80^{\circ} \mathrm{C}$ for $12 \mathrm{~h}$. After cooling to room temperature, the mixture was diluted with water $(200 \mathrm{~mL})$ followed by extraction with $\mathrm{CH}_{2} \mathrm{Cl}_{2}(300 \mathrm{~mL})$. The organic layer was washed with brine $(100 \mathrm{~mL})$, and then dried over anhydrous $\mathrm{MgSO}_{4}$, and filtered. After concentration of the filtrate under reduced pressure, the resulting mixture was purified by silica gel column chromatography to afford $1.80 \mathrm{~g}$ (11.3mmol, 75\%) of 2-(4-(dimethylamino)phenyl)acetonitrile as yellow oil. ${ }^{1} \mathrm{H}$ NMR (400 MHz, DMSO-d6): $\delta$ 7.19-7.14 (m, 2H), 6.77-6.73 (m, 2H), $3.87(\mathrm{~s}, 2 \mathrm{H}), 2.91(\mathrm{~s}$, $6 \mathrm{H})$.

2-(4-(Diethylamino)phenyl)acetonitrile. This compound was prepared in a similar manner as described for 2-(4-(dimethylamino)phenyl)acetonitrile using 2-(4-aminophenyl) acetonitrile $(2.00 \mathrm{~g}, 15.0 \mathrm{mmol})$ and bromoethane $(9.80 \mathrm{~g}, 90.0 \mathrm{mmol})$ as starting materials. 
Purification by silica gel column chromatography to afford $2.00 \mathrm{~g}$ (10.6 mmol, 71\%) of 2-(4(diethylamino)phenyl)acetonitrile as yellow oil. ${ }^{1} \mathrm{H}$ NMR (500 MHz, $\left.\mathrm{CDCl}_{3}\right): \delta 7.18-7.14(\mathrm{~m}$, 2H), 6.69-6.66 (m, 2H), 3.65 (s, 2H), 3.37 (m, 4H), 1.18 (m, 6H).

Compound 1. To a solution of 2-(4-(dimethylamino)phenyl)acetonitrile (1.60 g 10.0 $\mathrm{mmol})$ and terephthalaldehyde $(0.670 \mathrm{~g}, 5.00 \mathrm{mmol})$ in $t$-BuOH $(40 \mathrm{~mL})$ and THF $(20 \mathrm{~mL})$ was added potassium tert-butoxide $(1.12 \mathrm{~g}, 10.0 \mathrm{mmol})$ and tetrabutylammonium hydroxide $(3.40 \mathrm{~g}, 10.0 \mathrm{mmol})$, and the resulting mixture was stirred at $50{ }^{\circ} \mathrm{C}$ for $4 \mathrm{~h}$. After cooling to room temperature, the mixture was poured into $\mathrm{MeOH}(100 \mathrm{~mL})$. The precipitate was filtered and further purified by silica gel chromatography to afford $1.00 \mathrm{~g}(2.40 \mathrm{mmol}, 48 \%)$ of compound 1 as dark red powders. ${ }^{1} \mathrm{H}$ NMR (500 MHz, $\left.\mathrm{CDCl}_{3}\right): \delta 7.96(\mathrm{~s}, 4 \mathrm{H}), 7.63$ (d, $J=$ $8.5 \mathrm{~Hz}, 4 \mathrm{H}), 7.40(\mathrm{~s}, 2 \mathrm{H}), 6.87(\mathrm{~s}, 4 \mathrm{H}), 3.08(\mathrm{~s}, 12 \mathrm{H})$. A satisfactory ${ }^{13} \mathrm{C}$ NMR spectrum was not obtained due to the poor solubility. MS (MALDI-TOF): $m / z$ calcd. for $\mathrm{C}_{28} \mathrm{H}_{26} \mathrm{~N}_{4}: 418.2$ $\left(\left[M^{+}\right]\right)$; found. 418.6 .

Lipi-DSB. This compound was prepared in a similar manner as described for compound 1 using 2-(4-(diethylamino)phenyl)acetonitrile (1.88 g, $10.0 \mathrm{mmol})$ and terephthalaldehyde $(0.670 \mathrm{~g}, 5.00 \mathrm{mmol})$ as starting materials. Purification by silica gel column chromatography to afford $1.20 \mathrm{~g}$ (2.53 mmol, 51\%) of Lipi-DSB as red powders. ${ }^{1} \mathrm{H}$ NMR (500 $\mathrm{MHz}, \mathrm{CDCl}_{3}$ ): $\delta 7.94(\mathrm{~s}, 4 \mathrm{H}), 7.59(\mathrm{~s}, 4 \mathrm{H}), 7.35(\mathrm{~s}, 2 \mathrm{H}), 6.73(\mathrm{~s}, 4 \mathrm{H}), 3.44$ (d, J=7.5 Hz, 8H), $1.24(\mathrm{t}, J=7.1$ $\mathrm{Hz}, 12 \mathrm{H}) .{ }^{13} \mathrm{C} \mathrm{NMR}\left(126 \mathrm{MHz}, \mathrm{CDCl}_{3}\right): \delta 148.46,135.37,135.16,129.16,127.31,121.01$, 118.37, 112.21, 111.51, 44.47, 12.59. MS (MALDI-TOF): $m / z$ calcd. forC $_{32} \mathrm{H}_{34} \mathrm{~N}_{4}$ : 474.3([$\left.\left.M^{+}\right]\right)$; found. 474.7 .

1,4-Bis[(1E)-2-(4-bromophenyl)ethenyl]benzene. This compound was prepared in a similar manner as described for compound 1 using 2-(4-bromophenyl)acetonitrile (1.95 g, $10.0 \mathrm{mmol})$ and terephthalaldehyde $(0.670 \mathrm{~g}, 5.00 \mathrm{mmol})$ as starting materials. Purification by silica gel column chromatography to afford $2.00 \mathrm{~g}(4.10 \mathrm{mmol}, 82 \%)$ of 1,4-bis[(1E)-2- (4bromophenyl)ethenyl]benzene as yellow solids. ${ }^{1} \mathrm{H}$ NMR (500 MHz, $\left.\mathrm{CDCl}_{3}\right): \delta 8.02(\mathrm{~s}, 4 \mathrm{H})$, $7.65-7.59(\mathrm{~m}, 8 \mathrm{H}), 7.57(\mathrm{~s}, 2 \mathrm{H})$.

Compound 2. To a suspension of 1,4-bis[(1E)-2-(4-bromophenyl)ethenyl]benzene $(0.750$ $\mathrm{g}, 1.50 \mathrm{mmol})$ and $\mathrm{Cs}_{2} \mathrm{CO}_{3}(1.90 \mathrm{~g}, 6.00 \mathrm{mmol})$ in dry toluene $(30 \mathrm{~mL})$ was sequentially added $\mathrm{Pd}(\mathrm{OAc})_{2} \quad(60.0 \quad \mathrm{mg}, \quad 0.075 \quad \mathrm{mmol}), \quad$ 2-dicyclohexylphosphino-2',4',6'triisopropylbiphenyl (XPhos, $0.075 \mathrm{~g}, 0.15 \mathrm{mmol}$ ) and piperidine $(3 \mathrm{~mL}, 30.0 \mathrm{mmol})$, and the resulting mixture was stirred at $120{ }^{\circ} \mathrm{C}$ for $18 \mathrm{~h}$. After cooling to room temperature, water $(300 \mathrm{~mL})$ was added and mixture was extracted with dichloromethane $(400 \mathrm{~mL})$. The organic layer was washed with brine $(100 \mathrm{~mL})$, and then dried over anhydrous $\mathrm{MgSO}_{4}$, and filtered. 
After concentration of the filtrate under reduced pressure, the resulting mixture was purified by silica gel column chromatography to afford $0.420 \mathrm{~g}(0.840 \mathrm{mmol}, 56 \%)$ of compound 2 as orange red powders. ${ }^{1} \mathrm{H}$ NMR $\left(500 \mathrm{MHz}, \mathrm{CDCl}_{3}\right): \delta 7.96(\mathrm{~s}, 4 \mathrm{H}), 7.62(\mathrm{~s}, 4 \mathrm{H}), 7.41(\mathrm{~s}, 2 \mathrm{H})$, $6.97(\mathrm{~s}, 4 \mathrm{H}), 3.32(\mathrm{~s}, 8 \mathrm{H}), 1.70(\mathrm{~m}, 12 \mathrm{H})$. A satisfactory ${ }^{13} \mathrm{C}$ NMR spectrum was not obtained due to the poor solubility. MS (MALDI-TOF): $m / z$ calcd. for $\mathrm{C}_{34} \mathrm{H}_{34} \mathrm{~N}_{4}$ : 498.3 ([ $\left.M^{+}\right]$); found. 498.7.

\section{Photophysical Properties}

Measurements. UV-vis absorption spectra of solutions were measured with a Shimadzu UV-2550 spectrometer. Emission spectra of solutions were measured with an Ocean QE Pro fibre optic spectrometer. Absolute fluorescence quantum yields $\left(\Phi_{\mathrm{F}}\right)$ of solutions were determined with an Ocean QE Pro fibre optic spectrometer equipped with a calibrated integrating sphere system. Fluorescence lifetimes of solutions were measured using an Edinburgh FLS920 spectrometer equipped with a $365 \mathrm{~nm}$ LED excitation source. The fluorescence decay profiles of solutions were fitted reasonably well with a single exponential function.

\section{Cell Experiments}

Cell culture. In general, HeLa cells were cultured in Dulbecco's modified Eagle's medium (DMEM, high glucose, pyruvate) containing 10\% fetal bovine serum (FBS) and 1\% Antibiotic-Antimycotic (AA) at $37{ }^{\circ} \mathrm{C}$ in a humidified $5 \%(\mathrm{vol} / \mathrm{vol}) \mathrm{CO}_{2}$ incubator.

Cell viability assays. The effect of probe Lipi-DSB on cell viability was analyzed using 3-(4,5-dimethylthiazol-2-yl)-2,5-diphenyltetrazolium bromide (MTT). Cells were seeded into a flat-bottomed 96-well plate $\left(1 \times 10^{4}\right.$ cells/well $)$ and incubated in DMEM containing 10\% FBS (DMEM+) at $37{ }^{\circ} \mathrm{C}$ in a $5 \% \mathrm{CO}_{2} / 95 \%$ air incubator for $24 \mathrm{~h}$. The medium was then replaced with a culture medium DMEM+ containing various concentrations of Lipi-DSB (0, 0.5, 1.0, 2.0, 5.0 and 10.0 $\mu \mathrm{M}$ ) and 1\% DMSO. After incubation for $24 \mathrm{~h}$, MTT reagent (final concentration, $0.5 \mathrm{mg} / \mathrm{mL}$ ) was added to each well, and the plates were incubated for another $4 \mathrm{~h}$ in a $\mathrm{CO}_{2}$ incubator. Excess MTT tetrazolium solution was then removed. After the formazan crystals were solubilized in DMSO $(100 \mu \mathrm{L} /$ well) for $30 \mathrm{~min}$ at room temperature, the absorbance of each well was measured by a microplate reader (Bio-Tek Instruments, Inc) with an excitation at $490 \mathrm{~nm}$. Base on the MTT data, the IC50 value was obtained by data statistical analysis software (SPSS Statistics, Version number:18.0.0.282). 
Co-staining experiments. HeLa cells $\left(5 \times 10^{4}\right)$ were seeded in glass-bottom dishes two days before imaging. After removal of the medium, the cells were stained in DMEM+ containing probes $(2 \mu \mathrm{M}$ Lipi-DSB and $500 \mathrm{nM}$ Ph-Red, or $2 \mu \mathrm{M}$ molecule 1 and $500 \mathrm{nM}$ PhRed, or $2 \mu \mathrm{M}$ compound 2 and $200 \mathrm{nM}$ Ph-Red) and $1 \% \mathrm{DMSO}$ for $2 \mathrm{~h}$ in a $\mathrm{CO}_{2}$ incubator. After washing with fresh medium to remove the free probes, the cells were kept in HBSS for imaging. The confocal images were recorded using a Nikon A1RMP microscope or a Leica TCS SP8 microscope with following set: $\lambda_{\mathrm{ex}}=488 \mathrm{~nm}, \lambda_{\mathrm{em}}=500-540 \mathrm{~nm}$ for Lipi-DSB, 1 and $2 ; \lambda_{\mathrm{ex}}=488 \mathrm{~nm}, \lambda_{\mathrm{em}}=680-720 \mathrm{~nm}$ for Rh-Red. For the co-staining experiment of lysosomes, the cells were stained with Lipi-DSB $(2 \mu \mathrm{M}$ for $2 \mathrm{~h}$ ) followed by labeling with LysoTracker Deep Red (50 $\mathrm{nM}$ for $20 \mathrm{~min}$ ). Without washing, cell images were recorded with following set: $\lambda_{\mathrm{ex}}=488 \mathrm{~nm}, \lambda_{\mathrm{em}}=500-550 \mathrm{~nm}$ for Lipi-DSB, $\lambda_{\mathrm{ex}}=650 \mathrm{~nm}, \lambda_{\mathrm{em}}=700-750 \mathrm{~nm}$ for LysoTracker Deep Red.

General staining procedure of fluorescent probes. Live HeLa cells were stained in DMEM+ containing $2 \mu \mathrm{M}$ fluorescent probe (Lipi-DSB, molecule 1, molecule $\mathbf{2}$, or Nile Red) and $1 \%$ DMSO for $2 \mathrm{~h}$ in a $\mathrm{CO}_{2}$ incubator. Then, the cells were washed three times with fresh medium to remove the free probes, and kept in HBSS for confocal imaging and STED imaging.

Confocal imaging. For the comparison of LDs staining specificity of fluorescent probes, the confocal images were recorded using a Nikon A1RMP microscope with following set: $\lambda_{\text {ex }}$ $=488 \mathrm{~nm}, \lambda_{\mathrm{em}}=500-720 \mathrm{~nm}$. For the comparison of the photostability of fluorescent probes, the confocal images were recorded using a Nikon A1RMP microscope with an identical power of excitation laser $(488 \mathrm{~nm})$. The total signal intensities of each image were measured with ImageJ, normalized to the value of the first image and plotted as a function of the number of recorded confocal images. For the measurement of emission spectrum of Lipi-DSB in LDs of living HeLa cells, the images were recorded on a Leica TCS SP8 system by lambda scan in the range of $500 \mathrm{~nm}$ to $780 \mathrm{~nm}$ with a step of $5 \mathrm{~nm}$. The $488 \mathrm{~nm}$ laser was used for excitation.

STED imaging. The Leica TCS SP8 STED system with two continuous wave lasers at $592 \mathrm{~nm}$ and $660 \mathrm{~nm}$ for the depletion was used for STED imaging. A HyD detector and a STED WHITE objective (100x/1.40 OIL) were employed. Unless otherwise noted, the STED images were acquired with excitation at $488 \mathrm{~nm}$ (WLL), emission in the range of 500-640 nm, and depletion at $660 \mathrm{~nm}\left(\mathrm{CW}-\mathrm{STED}, 40 \mathrm{MW} \mathrm{cm}^{-2}\right)$. In general, the images were recorded with a pixel resolution of $22.7 \mathrm{~nm} \times 22.7 \mathrm{~nm}$, a scan speed of $100 \mathrm{~Hz}$, and a bidirectional model. The images were processed using ImageJ. The full width at half maximum (FWHM) 
resolution was determined based on the Gaussian fitting of the signal intensity profiles crossed the LDs.

Two-color STED imaging. Live HeLa cells were stained in DMEM+ containing $50 \mathrm{nM}$ tetramethylrhodamine methyl ester (TMRM) and 1\% DMSO for $20 \mathrm{~min}$ in a $\mathrm{CO}_{2}$ incubator. After washing with fresh medium, the cells were further stained in DMEM+ containing $2 \mu \mathrm{M}$ Lipi-DSB and $1 \%$ DMSO for $2 \mathrm{~h}$ in a $\mathrm{CO}_{2}$ incubator. Then, the cells were washed three times with fresh medium to remove the free probes, and kept in HBSS for STED imaging. LipiDSB and TMRM were excited at 470 and $550 \mathrm{~nm}$, respectively, in a line-by-line sequential scan mode. The same STED laser at $660 \mathrm{~nm}$ and the identical HyD detector $\left(\lambda_{\mathrm{em}}=560-640\right.$ $\mathrm{nm})$ were used for imaging. The STED images were recorded with a pixel resolution of 22.7 $\mathrm{nm} \times 22.7 \mathrm{~nm}$, a scan speed of $100 \mathrm{~Hz}$, and a bidirectional model.

3D STED imaging. Live HeLa cells pre-stained with Lipi-DSB $(2 \mu \mathrm{M}, 2 \mathrm{~h})$ was fixed by 4\% paraformaldehyde for $15 \mathrm{~min}$ at room temperature. After washing three times with PBS, the cells were kept in PBS for imaging. The Z-stack STED images were recorded with following set: excitation at $488 \mathrm{~nm}$ (WLL), emission in the range of 500-640 nm, depletion at

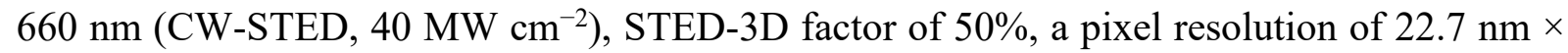
$22.7 \mathrm{~nm}$, a scan speed of $100 \mathrm{~Hz}$, and a bidirectional model. With a z-step of $50 \mathrm{~nm}, 105$ STED images were recorded in a z-depth of $5.20 \mu \mathrm{m}$. Employing the Leica LAS X software, the 3D STED image was reconstructed on the basis of the deconvoluted Z-stack STED images. 

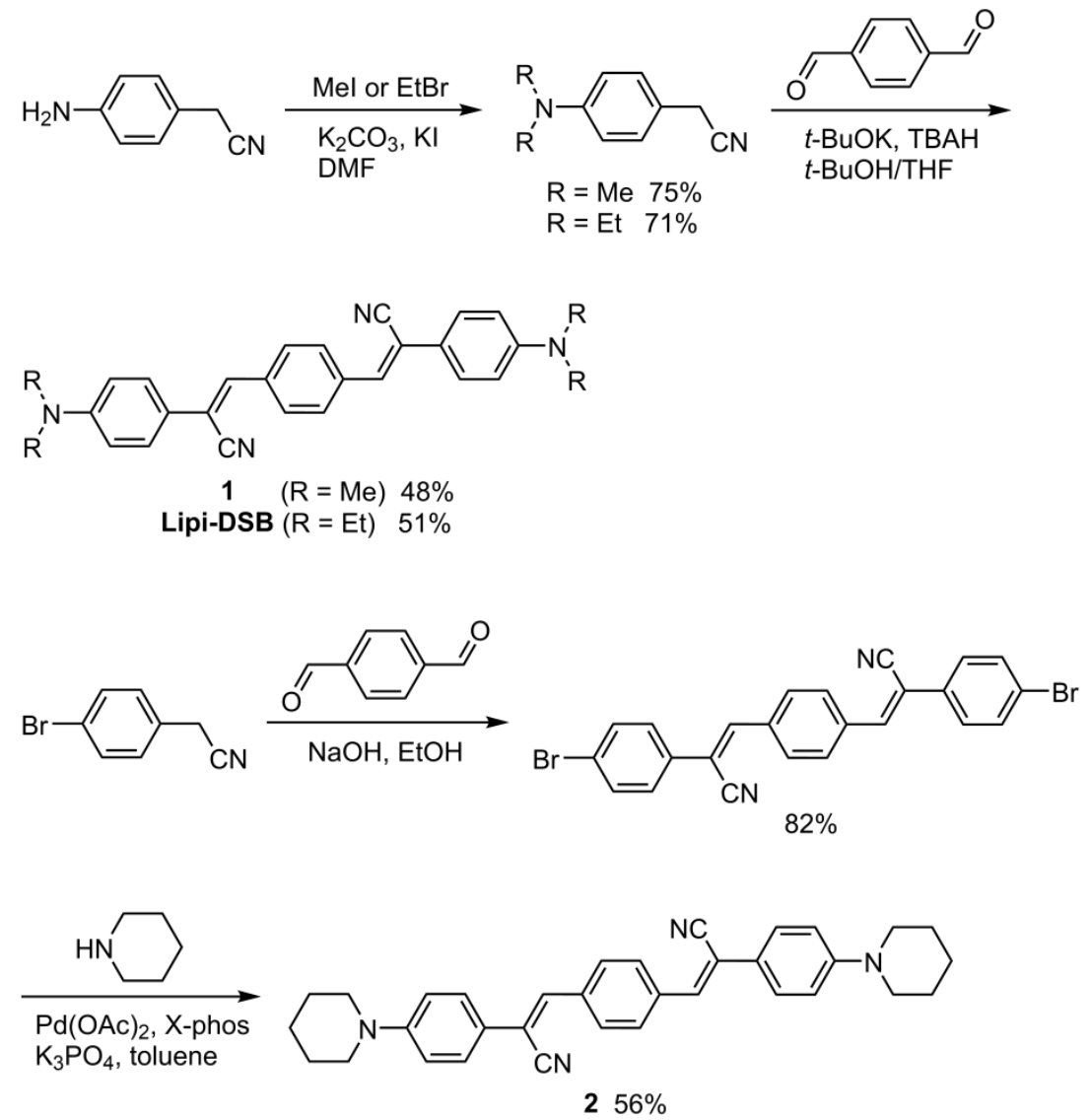

Scheme S1. Synthesis of the fluorescent probe Lipi-DSB and its derivatives 1-2. 
Table S1. Comparison of the Super-Resolution Imaging of LDs Reported in the Literatures

\begin{tabular}{|c|c|c|c|c|c|c|c|}
\hline Year & $\begin{array}{l}\text { Super- } \\
\text { resolution } \\
\text { imaging } \\
\text { technique }\end{array}$ & $\begin{array}{c}\text { Fluorescent } \\
\text { probe }\end{array}$ & $\begin{array}{c}\text { FWHM } \\
\text { resolution } \\
\text { of 2D image }\end{array}$ & $\begin{array}{l}\text { Time-lapse } \\
\text { super- } \\
\text { resolution } \\
\text { imaging }\end{array}$ & $\begin{array}{l}3 \mathrm{D} \text { super- } \\
\text { resolution } \\
\text { imaging }\end{array}$ & $\begin{array}{c}\text { FWHM } \\
\text { resolution } \\
\text { of 3D image }\end{array}$ & $\begin{array}{c}\text { Refer } \\
\text { ence }\end{array}$ \\
\hline 2018 & SIM & NIM-3A & $\begin{array}{c}\text { Not } \\
\text { mentioned }\end{array}$ & - & - & - & 1 \\
\hline 2019 & SIM & NIM-7 & $\begin{array}{c}\text { Not } \\
\text { mentioned }\end{array}$ & - & - & - & 2 \\
\hline 2019 & PALM & SNile Red & $<250 \mathrm{~nm}$ & - & - & - & 3 \\
\hline 2019 & STED & PyLa-C17Cer & $\sim 300 \mathrm{~nm}$ & 30 frames & - & - & 4 \\
\hline 2019 & STED & $\mathrm{CM} 2 \mathrm{P}$ & $\sim 300 \mathrm{~nm}$ & - & Yes & $\begin{array}{c}\text { Not } \\
\text { mentioned }\end{array}$ & 5 \\
\hline 2021 & STED & LAQ1 & $166 \mathrm{~nm}$ & - & - & - & 6 \\
\hline 2021 & STED & DTPA-BT-M & $95 \mathrm{~nm}$ & 11 frames & - & - & 7 \\
\hline $\begin{array}{l}\text { This } \\
\text { work }\end{array}$ & STED & Lipi-DSB & $58 \mathrm{~nm}$ & 1000 frames & Yes & $\begin{array}{l}\text { xy: } 77 \mathrm{~nm} \\
\mathrm{z}: 150 \mathrm{~nm}\end{array}$ & \\
\hline
\end{tabular}

Referecnces:

[1] X. Zheng, W. Zhu, F. Ni, H. Ai, C. Yang, Sensor. Actuat. B-Chem. 2018, 255, 3148.

[2] X. Zheng, W. Zhu, F. Ni, H. Ai, S. Gong, X. Zhou, J. L. Sessler, C. Yang, Chem. Sci. 2019, 10, 2342.

[3] J. Tang, M. A. Robichaux, K. L. Wu, J. Pei, N. T. Nguyen, Y. Zhou, T. G. Wensel, H. Xiao, J. Am. Chem. Soc. 2019, 141, 14699.

[4] D. O’ Connor, A. Byrne, G. B. Berselli, C. Long, T. E. Keyes, Analyst 2019, 144, 1608.

[5] H. Xu, H. Zhang, G. Liu, L. Kong, X. Zhu, X. Tian, Z. Zhang, R. Zhang, Z. Wu, Y. Tian, H. Zhou, Anal. Chem. 2019, 91, 977.

[6] M. Taki, K. Kajiwara, E. Yamaguchi, Y. Sato, S. Yamaguchi, ACS Materials Lett. 2021, 3, 42.

[7] Y. Xu, H. Zhang, N. Zhang, R. Xu, Z. Wang, Y. Zhou, Q. Shen, D. Dang, L. Meng and B. Z. Tang, Mater. Chem. Front. 2021, DOI: 10.1039/D0QM00682C. 


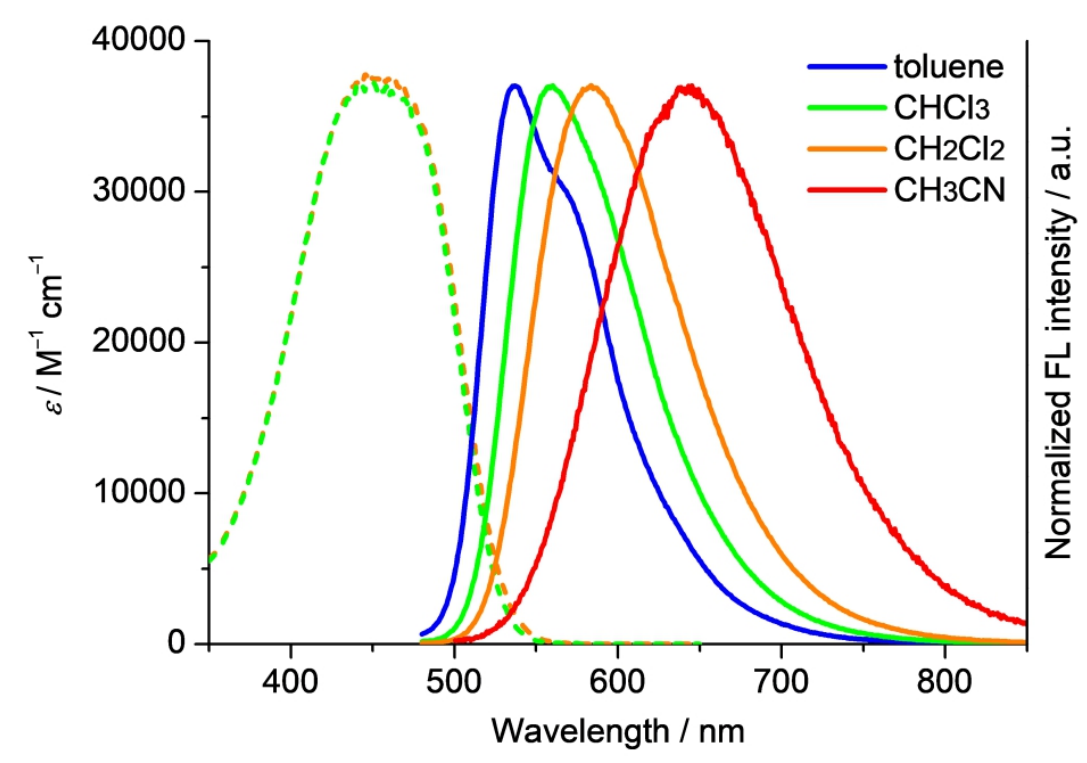

Figure S1. The absorption (dashed line) and fluorescence (solid line) spectra of molecule $\mathbf{1}$ in various organic solvents.

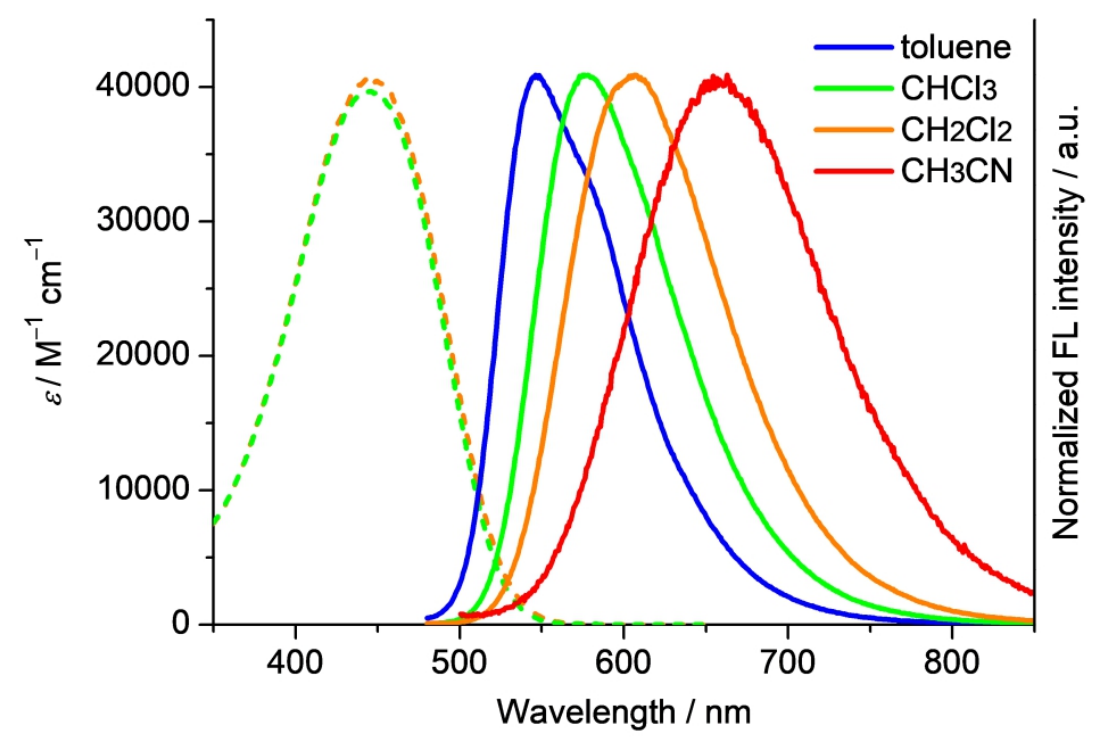

Figure S2. The absorption (dashed line) and fluorescence (solid line) spectra of molecule 2 in various organic solvents. 
Table S2. Photophysical Data for Lipi-DSB and Its Derivatives 1-2 in Solutions

\begin{tabular}{|c|c|c|c|c|c|c|c|c|}
\hline Compound & Solvent & $\begin{array}{l}\lambda_{\mathrm{abs}} / \\
\mathrm{nm}^{a}\end{array}$ & $\begin{array}{c}\varepsilon / 10^{4} \\
\mathrm{M}^{-1} \mathrm{~cm}^{-1}\end{array}$ & $\begin{array}{c}\lambda_{\mathrm{em}} / \\
\mathrm{nm}\end{array}$ & $\Phi_{\mathrm{F}}^{b}$ & $\tau / \mathrm{ns}$ & $\begin{array}{c}k_{\mathrm{r}} / 10^{8} \\
\mathrm{~s}^{-1}\end{array}$ & $\begin{array}{c}k_{\mathrm{nr}} / \\
10^{8} \mathrm{~s}^{-1}\end{array}$ \\
\hline \multirow{4}{*}{ Lipi-DSB } & toluene & 465 & 4.28 & 540 & 0.97 & 1.98 & 4.9 & 0.15 \\
\hline & $\mathrm{CHCl}_{3}$ & 469 & 4.10 & 564 & 0.95 & 2.20 & 4.3 & 0.23 \\
\hline & $\mathrm{CH}_{2} \mathrm{Cl}_{2}$ & 469 & 4.51 & 588 & 0.93 & 2.38 & 3.9 & 0.29 \\
\hline & $\mathrm{CH}_{3} \mathrm{CN}$ & 462 & 4.31 & 636 & 0.65 & 2.36 & 2.8 & 1.5 \\
\hline \multirow{4}{*}{1} & toluene & 453 & $--^{c}$ & 537 & 0.82 & 1.86 & 4.4 & 1.0 \\
\hline & $\mathrm{CHCl}_{3}$ & 457 & 3.72 & 560 & 0.94 & 2.98 & 3.2 & 0.20 \\
\hline & $\mathrm{CH}_{2} \mathrm{Cl}_{2}$ & 457 & 3.78 & 584 & 0.88 & 2.54 & 3.5 & 0.47 \\
\hline & $\mathrm{CH}_{3} \mathrm{CN}$ & 445 & $---^{c}$ & 645 & 0.41 & 2.07 & 2.0 & 2.9 \\
\hline \multirow{4}{*}{$?$} & toluene & 445 & $---c$ & 546 & 0.89 & 1.92 & 4.6 & 0.57 \\
\hline & $\mathrm{CHCl}_{3}$ & 448 & 3.96 & 575 & 0.93 & 2.47 & 3.8 & 0.28 \\
\hline & $\mathrm{CH}_{2} \mathrm{Cl}_{2}$ & 448 & 4.08 & 606 & 0.93 & 2.57 & 3.6 & 0.27 \\
\hline & $\mathrm{CH}_{3} \mathrm{CN}$ & 458 & $---c$ & 663 & 0.31 & 2.50 & 1.2 & 2.8 \\
\hline
\end{tabular}

${ }^{a}$ The longest-wavelength absorption maximum.

${ }^{b}$ Absolute fluorescence quantum yield determined by a calibrated integrating sphere system (error: $\pm 3 \%$ ).

${ }^{c}$ The value was not determined due to the relative poor solubility. 

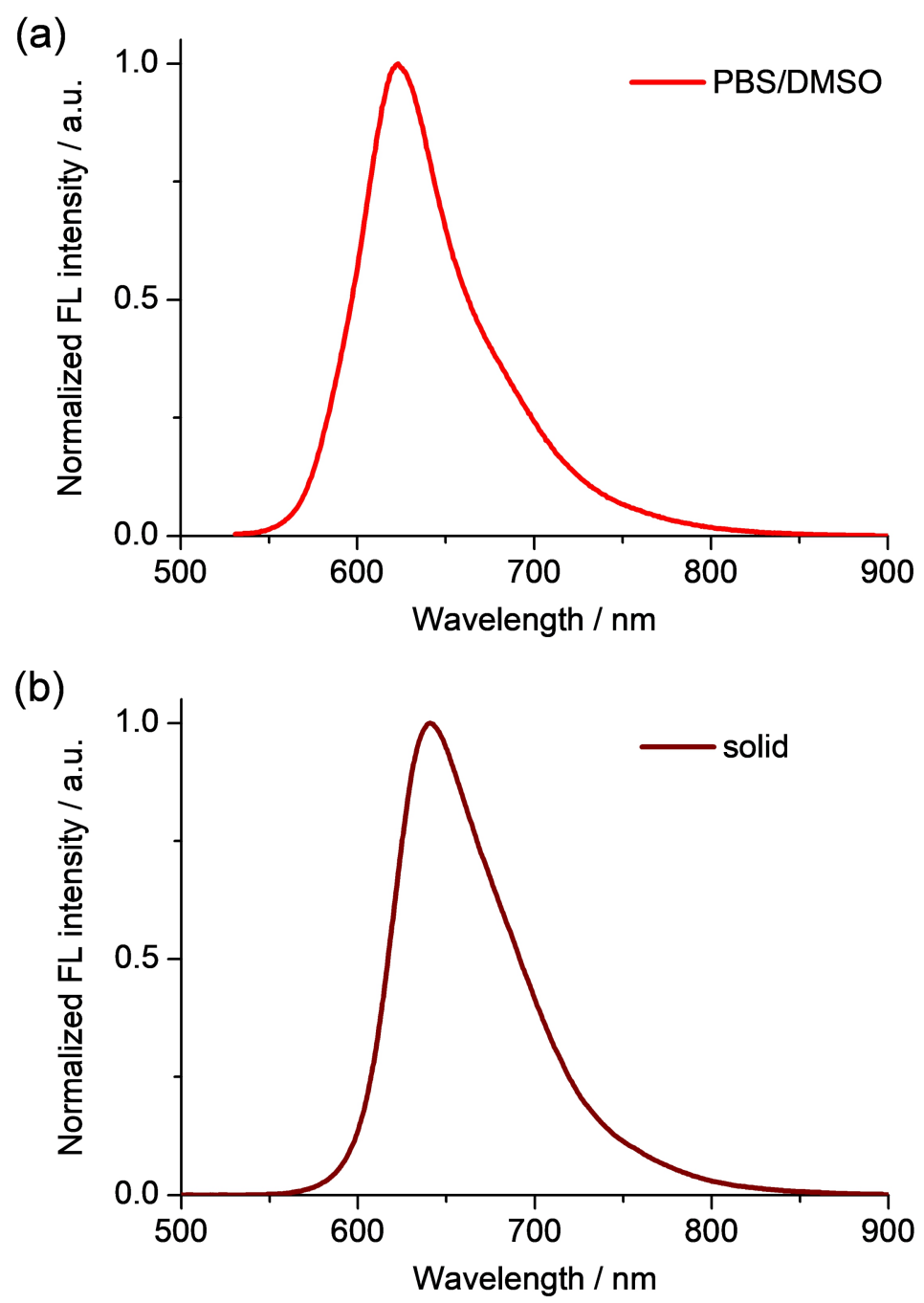

Figure S3. Normerlized emission spectra of Lipi-DSB in aqueous solution of PBS/DMSO $(\mathrm{V} / \mathrm{V}=3 / 7)$ or in solid state. 


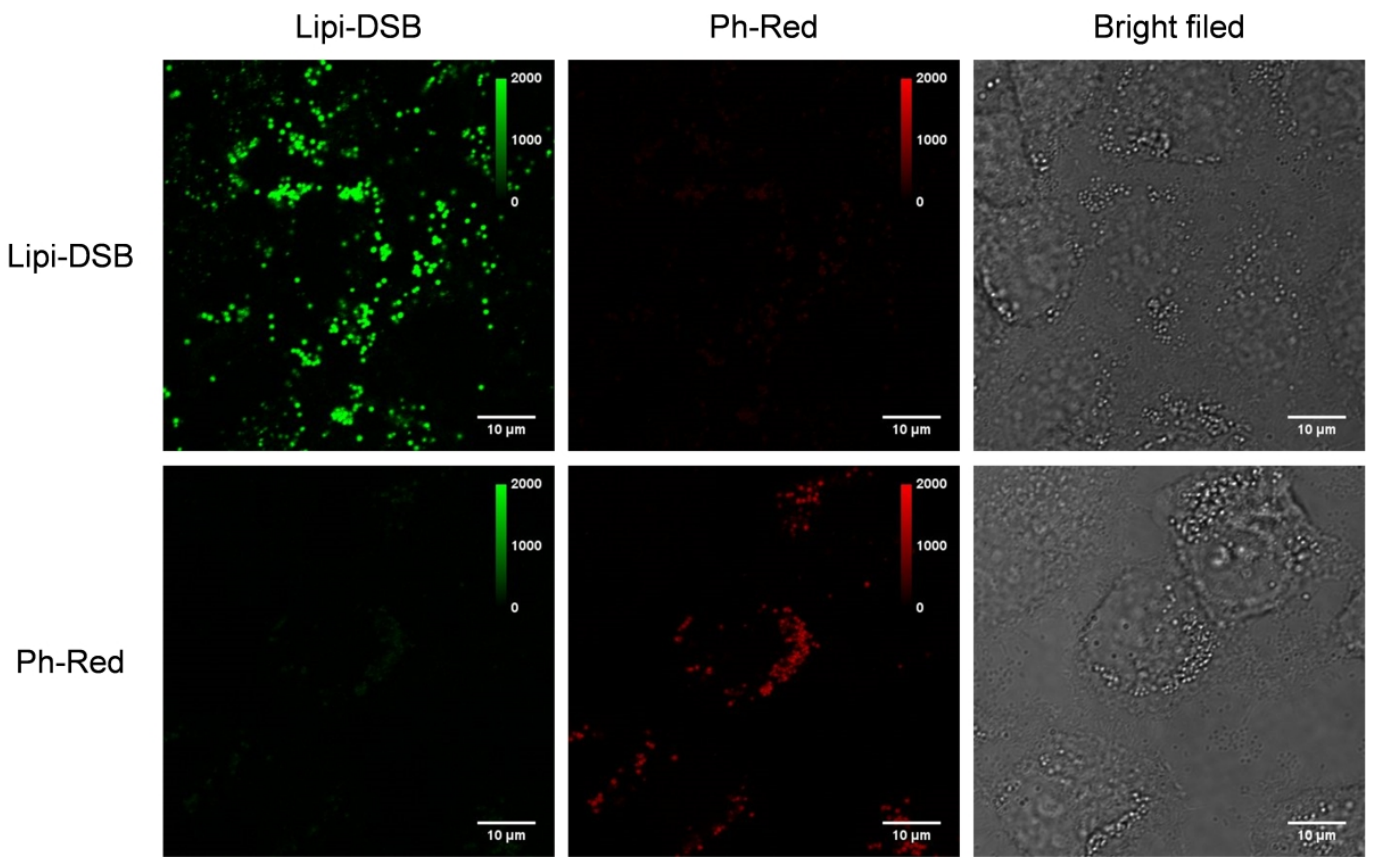

Figure S4. Verification of cross-talk between the two imaging channels for co-staining experiments. The living HeLa cells were separately stained with Lipi-DSB $(2 \mu \mathrm{M})$ or lipid droplets probe $\mathrm{Ph}-\mathrm{Red}(500 \mathrm{nM})$ for $2 \mathrm{~h}$. From left to right: imaging channel of Lipi-DSB ( $\lambda_{\mathrm{ex}}$ $\left.=488 \mathrm{~nm}, \lambda_{\mathrm{em}}=500-540 \mathrm{~nm}\right)$; imaging channel of Rh-Red $\left(\lambda_{\mathrm{ex}}=488 \mathrm{~nm}, \lambda_{\mathrm{em}}=680-720 \mathrm{~nm}\right)$; bright filed image. Scale bar: $10 \mu \mathrm{m}$. 

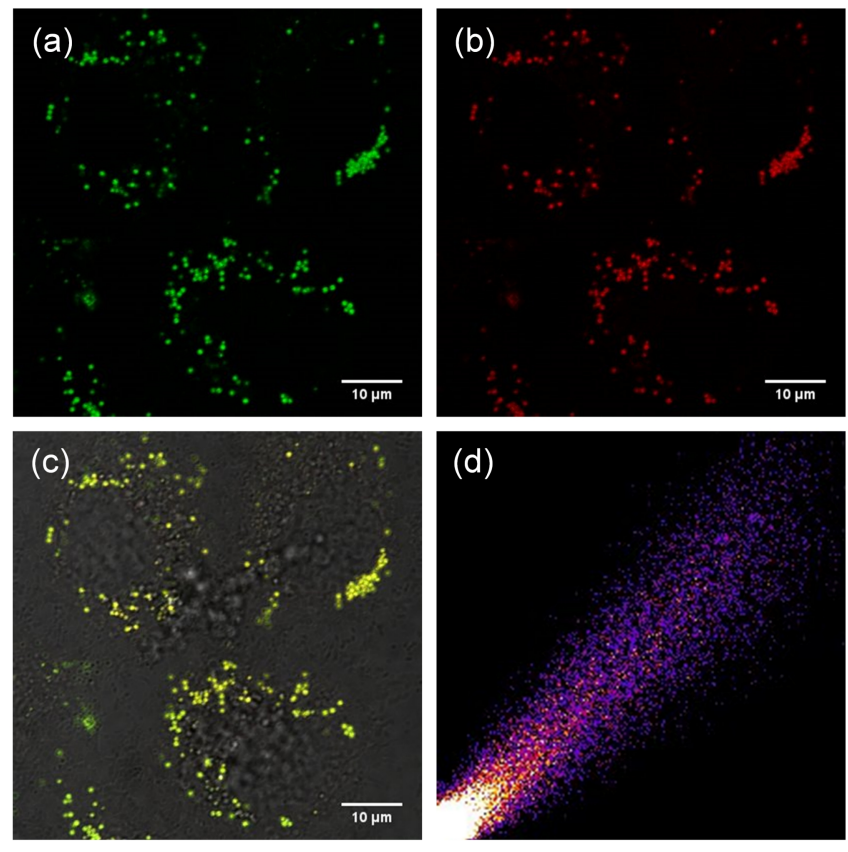

Figure S5. Co-localization confocal imaging of living HeLa cells stained with molecule $\mathbf{1}$ and the lipid droplets probe Ph-Red: (a) imaging channel of molecule $1\left(\lambda_{\mathrm{ex}}=488 \mathrm{~nm}, \lambda_{\mathrm{em}}=\right.$ $500-540 \mathrm{~nm})$; (b) imaging channel of Rh-Red $\left(\lambda_{\mathrm{ex}}=488 \mathrm{~nm}, \lambda_{\mathrm{em}}=680-720 \mathrm{~nm}\right)$; (c) merged image of two fluorescence channels and bright filed; (d) Pearson's correlation coefficient plot of the two fluorescence channels $(R=0.96)$. Scale bar: $10 \mu \mathrm{m}$. 

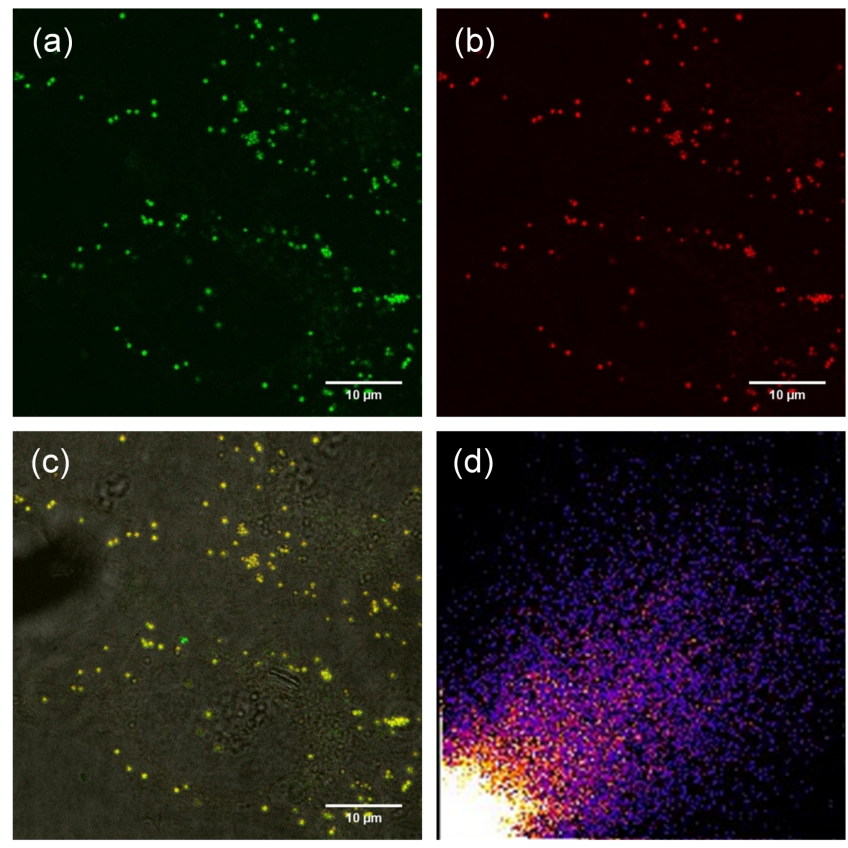

Figure S6. Co-localization confocal imaging of living HeLa cells stained with molecule $\mathbf{2}$ and the lipid droplets probe Ph-Red: (a) imaging channel of molecule $2\left(\lambda_{\mathrm{ex}}=488 \mathrm{~nm}, \lambda_{\mathrm{em}}=\right.$ $500-540 \mathrm{~nm}$ ); (b) imaging channel of Rh-Red $\left(\lambda_{\mathrm{ex}}=488 \mathrm{~nm}, \lambda_{\mathrm{em}}=680-720 \mathrm{~nm}\right)$; (c) merged image of two fluorescence channels and bright filed; (d) Pearson correlation coefficient plot of the two fluorescence channels $(R=0.70)$. Scale bar: $10 \mu \mathrm{m}$. 

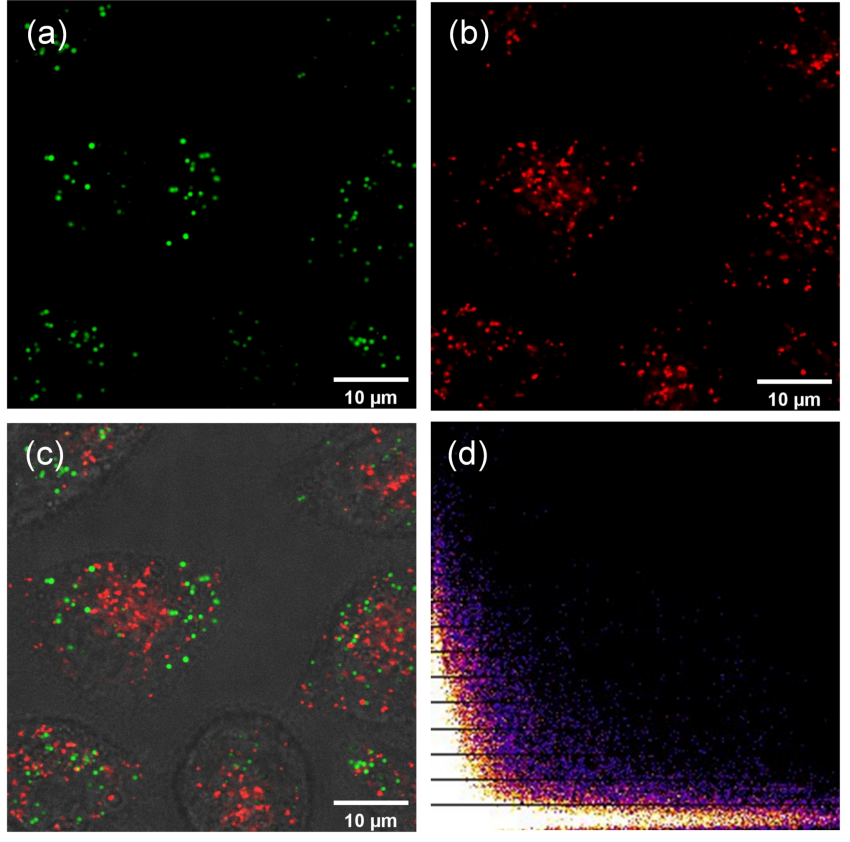

Figure S7. Co-localization confocal imaging of living HeLa cells stained with Lipi-DSB and the lysosome probe LysoTracker Deep Red: (a) imaging channel of Lipi-DSB ( $\lambda_{\mathrm{ex}}=488 \mathrm{~nm}$, $\left.\lambda_{\mathrm{em}}=500-550 \mathrm{~nm}\right)$; (b) imaging channel of LysoTracker Deep Red $\left(\lambda_{\mathrm{ex}}=650 \mathrm{~nm}, \lambda_{\mathrm{em}}=\right.$ 700-750 nm); (c) merged image of two fluorescence channels and bright filed; (d) Pearson correlation coefficient plot of the two fluorescence channels $(R=0.13)$. Scale bar: $10 \mu \mathrm{m}$. 
(a)
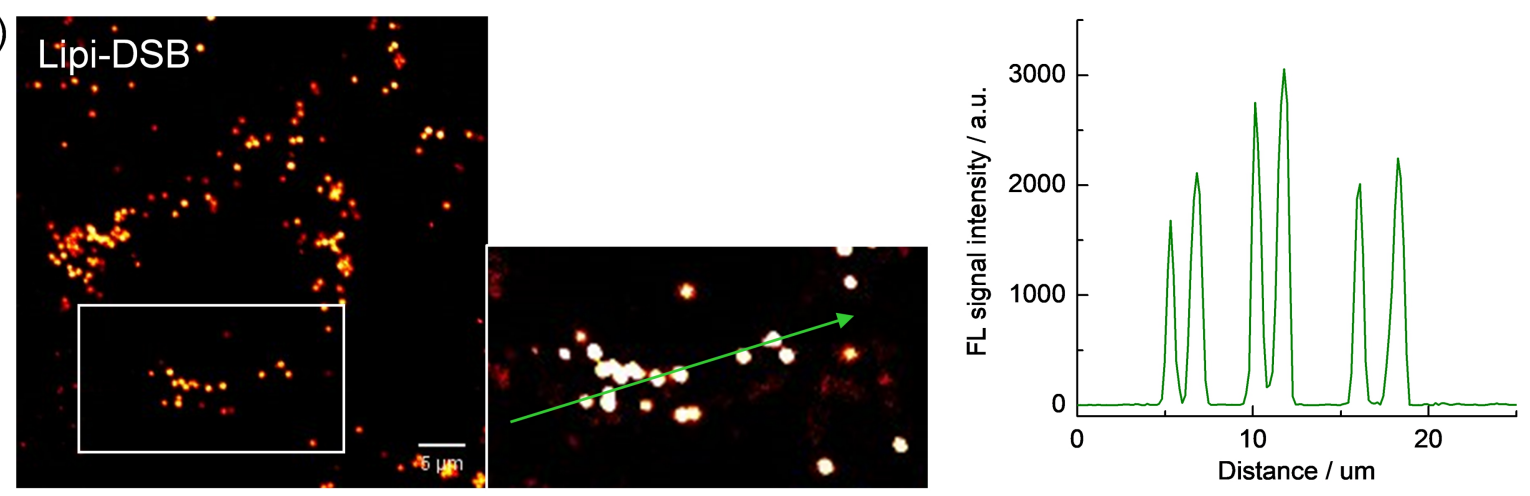

(b)
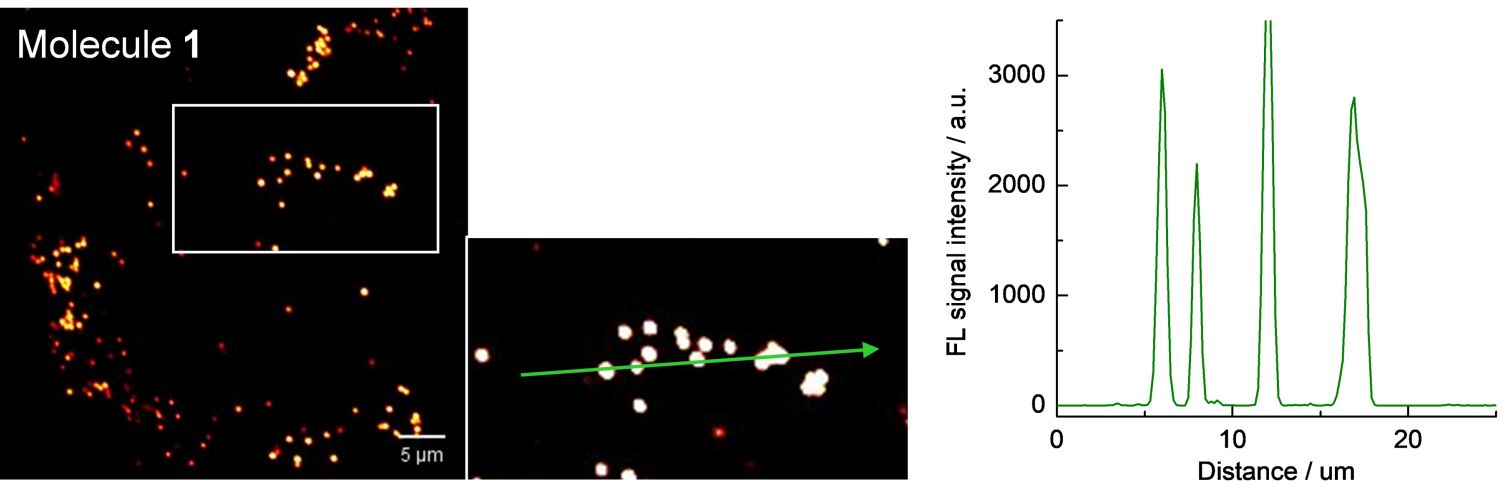

(c)
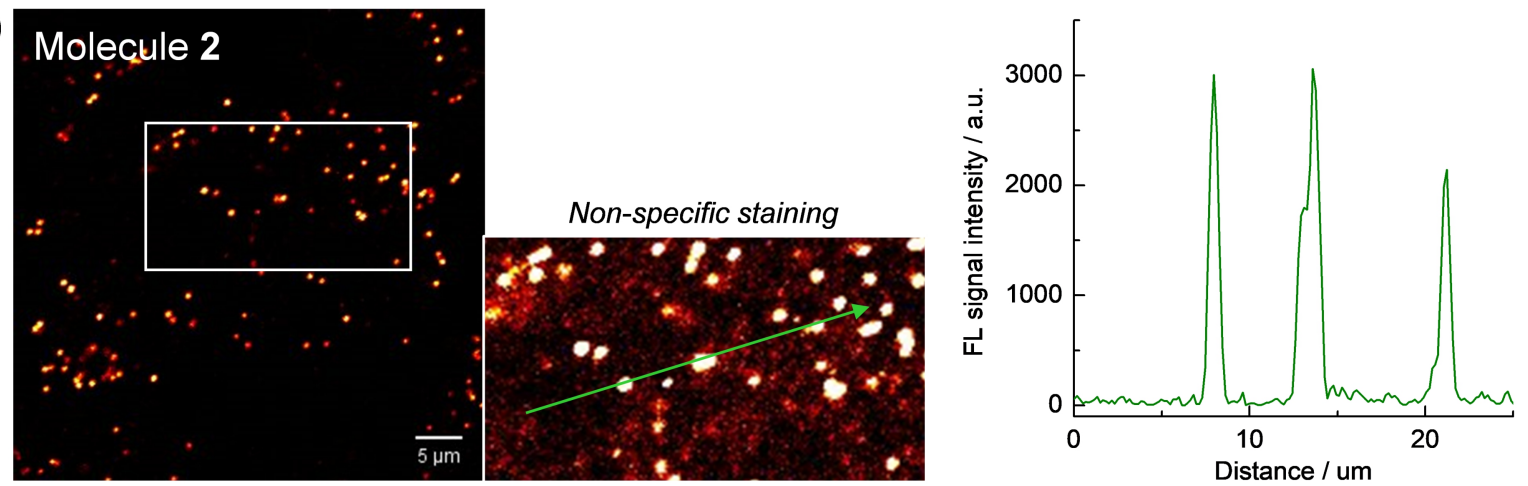

(d) Nile Red
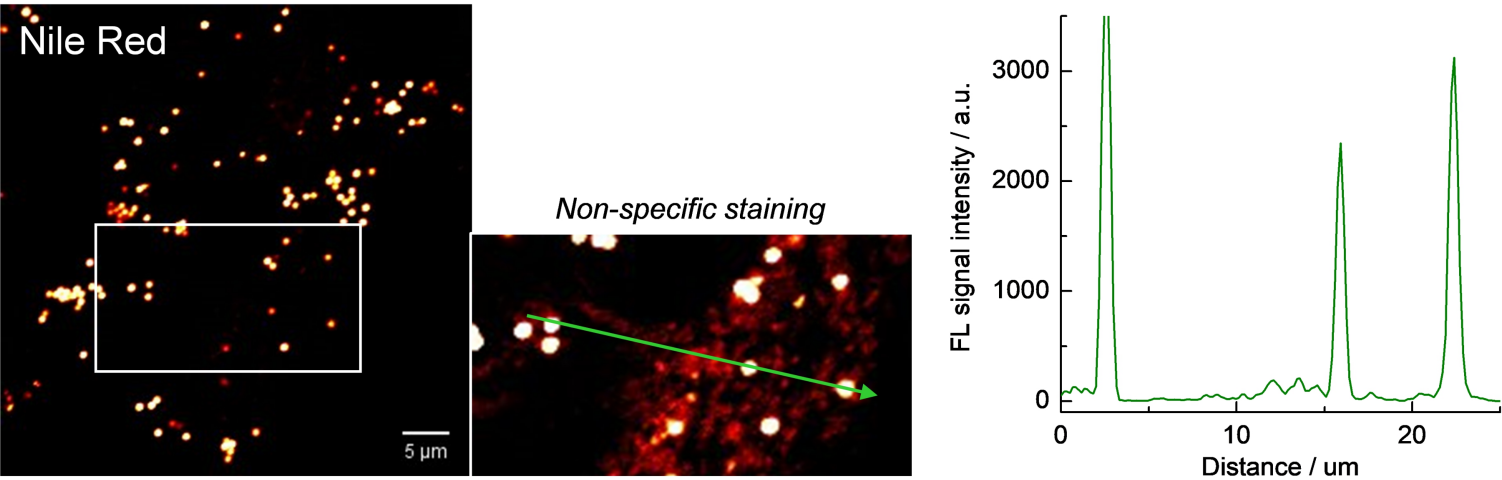

Figure S8. Comparison of the LDs staining specificity of various fluorescent probes in living HeLa cells: (a) Lipi-DSB; (b) molecule 1; (c) molecule 2; (d) Nile Red. Scale bar: $5 \mu \mathrm{m}$. The zoomed views of the square marked regions are shown in the insets. The signal intensity profiles crossed the LDs (indicated with arrows) are shown in the right column. 


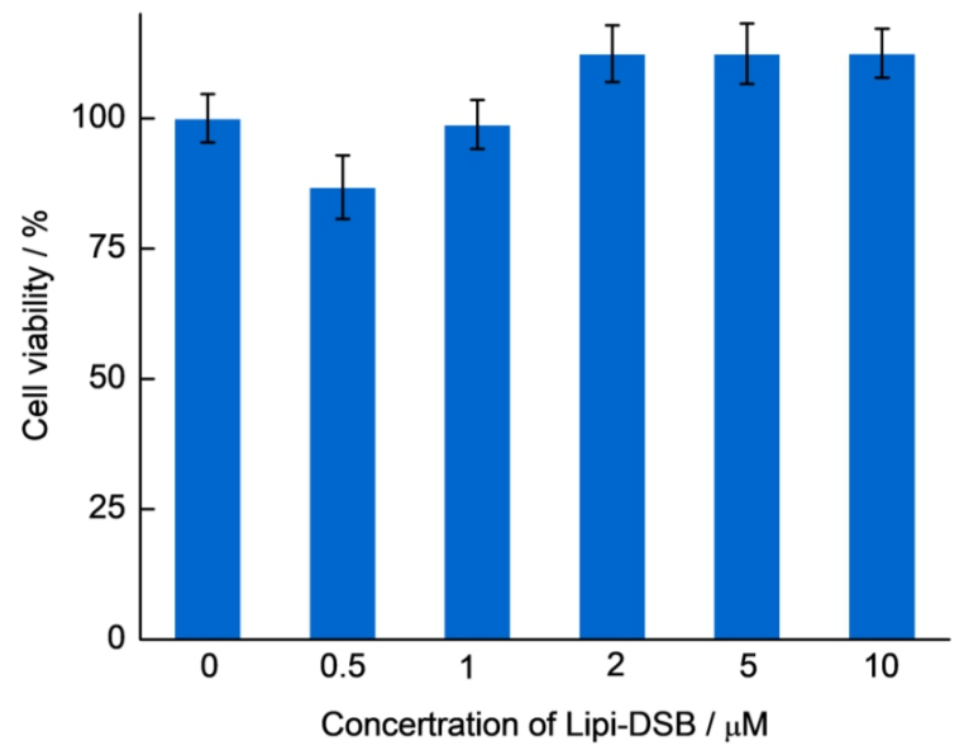

Figure S9. Cell viability results of the HeLa cells stained with Lipi-DSB by MTT assay. The results are expressed as percentages of the dye-free controls. All data are presented as mean \pm s.d. $(n=10)$. 


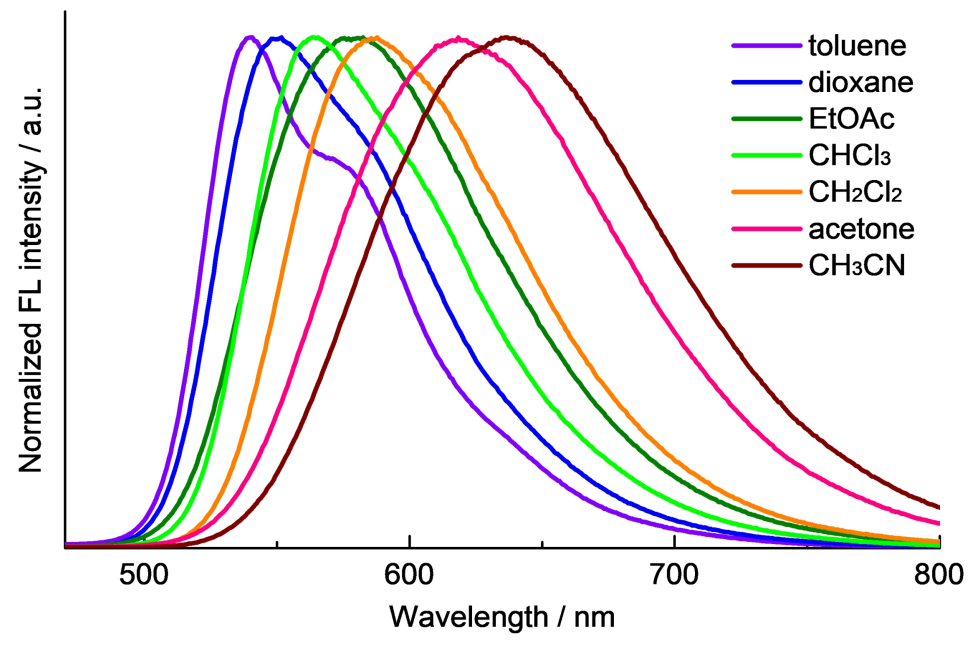

Figure S10. The fluorescence spectra of probe Lipi-DSB in organic solvents with variuos polarity index $E_{\mathrm{T}}(30)$.

Table S3. The Emission Maxima of Lipi-DSB as a Function of the Polarity Index $E_{\mathrm{T}}(30)$ of Various Solvents

\begin{tabular}{cccc}
\hline Solvent & $E_{\mathrm{T}}(30)$ & $\lambda_{\mathrm{em}} / \mathrm{nm}$ & $\lambda_{\mathrm{em}} / \mathrm{cm}^{-1}$ \\
\hline toluene & 33.9 & 540 & 18519 \\
1,4-dioxane & 36.0 & 551 & 18149 \\
$\mathrm{CH}_{3} \mathrm{COOC}_{2} \mathrm{H}_{5}$ & 38.1 & 583 & 17153 \\
$\mathrm{CHCl}_{3}$ & 39.1 & 564 & 17730 \\
$\mathrm{CH}_{2} \mathrm{Cl}_{2}$ & 40.7 & 588 & 17007 \\
$\mathrm{CH}_{3} \mathrm{COCH}_{3}$ & 42.2 & 619 & 16155 \\
$\mathrm{CH}_{3} \mathrm{CN}$ & 45.6 & 636 & 15723 \\
\hline Lipid droplets & 35.2 & $550^{b}$ & 18349 \\
\hline
\end{tabular}

${ }^{a}$ Lipid droples in living HeLa cells were stained with Lipi-DSB.

${ }^{b}$ Maximum emission wavelength measured by spectral imaging microscopy. 

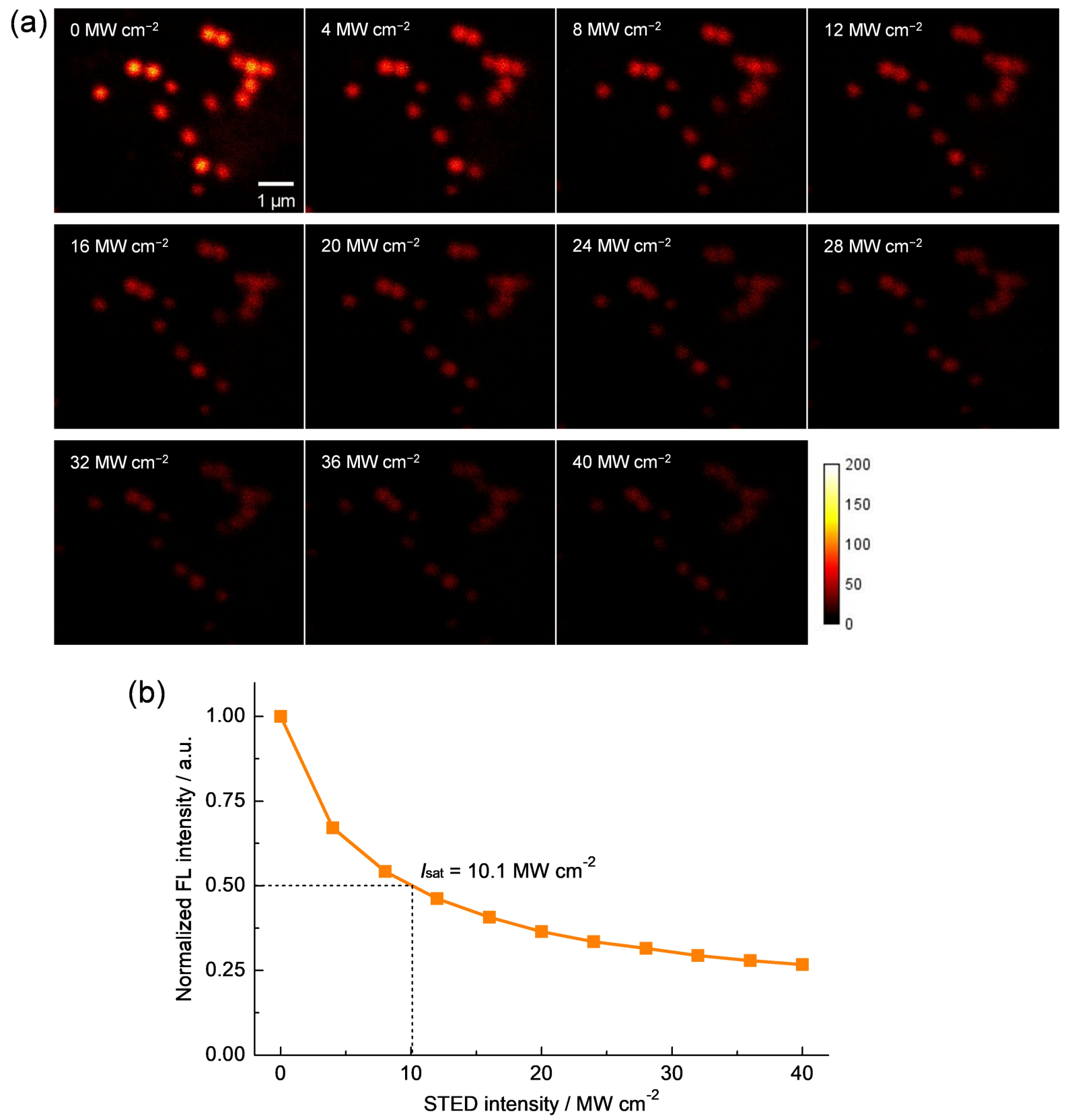

Figure S11. Determination of the saturation intensity $\left(I_{\text {sat }}\right)$ of Lipi-DSB under $660 \mathrm{~nm} \mathrm{CW-}$ STED laser: (a) the fluorescence images of HeLa cells stained with Lipi-DSB under the identical excitation condition $\left(\lambda_{\mathrm{ex}}=488 \mathrm{~nm}\right.$ ) while gradually increasing the STED laser power $(660 \mathrm{~nm})$ from 0 to $40 \mathrm{MW} \mathrm{cm}^{-2}$; (b) the fluorescence intensities of each image as a function of the STED laser intensities. 

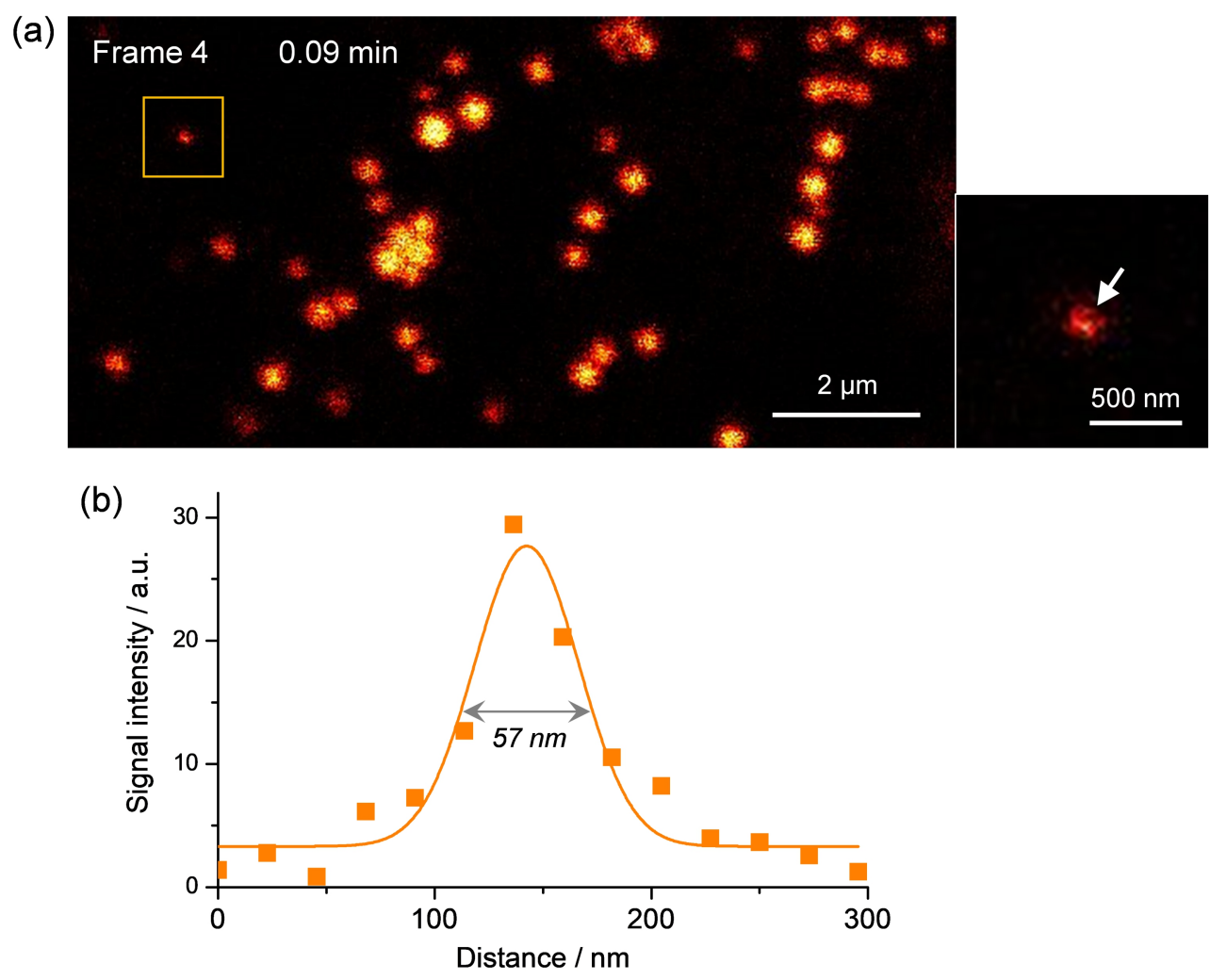

Figure S12. Determination of the FWHM resolution of time-lapse STED super-resolution imaging of Lipi-DSB. a) Frame 4 of time-lapse STED imaging (Movie S1); scale bar: $2 \mu \mathrm{m}$; the zoomed view of the square marked region is shown in the inset, scale bar: $500 \mathrm{~nm}$; the image is shown in raw data without deconvolution. b) The signal intensity profile crossed the LD (indicated with arrow), the FWHM resolution $(57 \pm 6 \mathrm{~nm})$ is calculated from a Gaussian fitting. 
Table S4. State-of-the-Art Performance of STED Super-Resolution Imaging Employing Various Organic Fluorescent Probes

\begin{tabular}{|c|c|c|c|c|c|c|c|}
\hline Year & $\begin{array}{c}\text { Fluorescent } \\
\text { probe }\end{array}$ & $\begin{array}{l}\text { Cellular } \\
\text { organelle }\end{array}$ & $\begin{array}{c}\text { FWHM } \\
\text { resolution } \\
\text { of } 2 \mathrm{D} \text { image }\end{array}$ & $\begin{array}{l}\text { Time-lapse } \\
\text { super- } \\
\text { resolution } \\
\text { imaging }\end{array}$ & $\begin{array}{l}3 \mathrm{D} \text { super- } \\
\text { resolution } \\
\text { imaging }\end{array}$ & $\begin{array}{c}\text { FWHM } \\
\text { resolution } \\
\text { of } 3 \mathrm{D} \text { image }\end{array}$ & $\begin{array}{l}\text { Refer } \\
\text { ence }\end{array}$ \\
\hline 2019 & $\begin{array}{l}\text { Mito-PB } \\
\text { Yellow }\end{array}$ & $\begin{array}{l}\text { mitochondrial } \\
\text { cristae }\end{array}$ & $58 \mathrm{~nm}$ & 700 frames & - & - & 1 \\
\hline 2019 & $\begin{array}{l}\text { COX8A- } \\
\text { SNAP }\end{array}$ & $\begin{array}{l}\text { mitochondrial } \\
\text { cristae }\end{array}$ & $\sim 50 \mathrm{~nm}$ & 16 frames & - & - & 2 \\
\hline 2020 & $\begin{array}{l}\text { MitoESq- } \\
635\end{array}$ & $\begin{array}{l}\text { mitochondrial } \\
\text { cristae }\end{array}$ & $35.2 \mathrm{~nm}$ & 51 frames & Yes & $\begin{array}{l}\text { xy: } 51 \mathrm{~nm} \\
\mathrm{z}: \sim 400 \mathrm{~nm}\end{array}$ & 3 \\
\hline 2014 & SiR-tubulin & tubulins & $39 \mathrm{~nm}$ & 20 frames & - & - & 4 \\
\hline 2017 & PB430-IgG & tubulins & $76 \mathrm{~nm}$ & 30 frames & Yes & $\mathrm{z}: 160 \mathrm{~nm}$ & 5 \\
\hline 2015 & SiR-Hoechst & DNA & $78 \mathrm{~nm}$ & - & - & - & 6 \\
\hline 2020 & $\begin{array}{l}\text { Lyso-PB } \\
\text { Yellow }\end{array}$ & $\begin{array}{l}\text { lysosome } \\
\text { membrane }\end{array}$ & $70 \mathrm{~nm}$ & - & - & - & 7 \\
\hline $\begin{array}{l}\text { This } \\
\text { work }\end{array}$ & Lipi-DSB & Lipid droplets & $58 \mathrm{~nm}$ & 1000 frames & Yes & $\begin{array}{l}\text { xy: } 77 \mathrm{~nm} \\
\text { z: } 150 \mathrm{~nm}\end{array}$ & \\
\hline
\end{tabular}

References:

[1] C. Wang, M. Taki, Y. Sato, Y. Tamura, H. Yaginuma, Y. Okada, S. Yamaguchi, Proc. Natl. Acad. Sci. USA 2019, 116, 15817.

[2] T. Stephan, A. Roesch, D. Riedel, S. Jakobs, Sci. Rep. 2019, 9, 12419.

[3] X. Yang, Z. Yang, Z. Wu, Y. He, C. Shan, P. Chai, C. Ma, M. Tian, J. Teng, D. Jin, W. Yan, P. Das, J. Qu, P. Xi, Nat. Commun. 2020, 11, 3699.

[4] G. Lukinavičius, L. Reymond, E. D'Este, A. Masharina, F. Göttfert, H. Ta, A. Güther, M. Fournier, S. Rizzo, H. Waldmann, C. Blaukopf, C. Sommer, D. W. Gerlich, H. D. Arndt, S. W. Hell, K. Johnsson, Nat. Methods 2014, 11, 731.

[5] C. Wang, M. Taki, Y. Sato, A. Fukazawa, T. Higashiyama, S. Yamaguchi, J. Am. Chem. Soc. 2017, 139, 10374.

[6] G. Lukinavičius, C. Blaukopf, E. Pershagen, A. Schena, L. Reymond, E. Derivery, M. GonzalezGaitan, E. D'Este, S. W. Hell, D. W. Gerlich, K. Johnsson, Nat. Commun. 2015, 6, 8497.

[7] C. Wang, M. Taki, K. Kajiwara, J. Wang, S. Yamaguchi, ACS Materials Lett. 2020, 2, 705. 


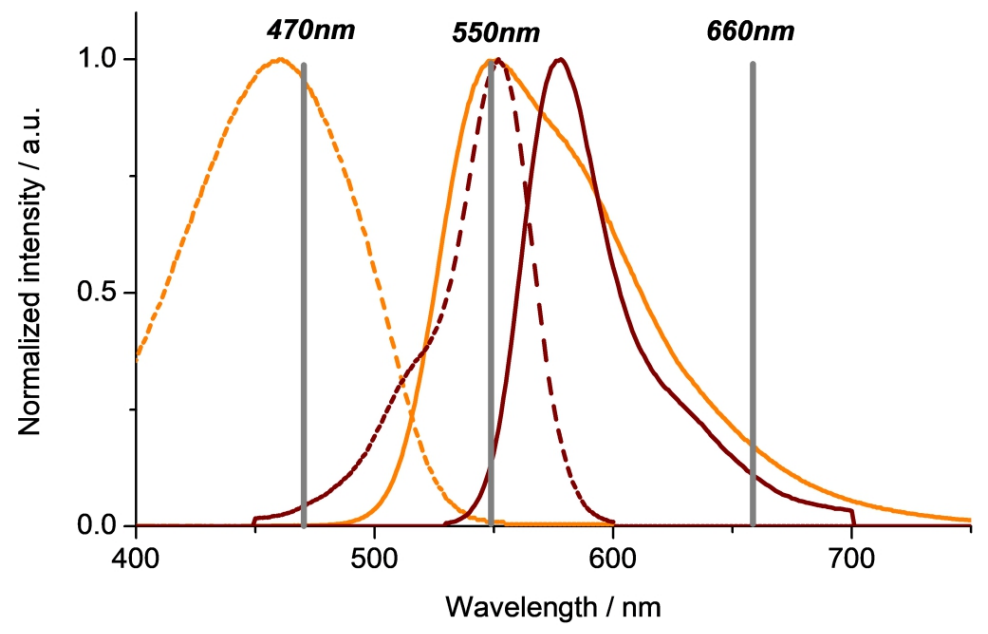

Figure S13. Normalized absorption and emission spectra of Lipi-DSB (orange line) and tetramethylrhodamine methyl ester (TMRM, dark brown line) with large and small Stokes shifts, respectively. 

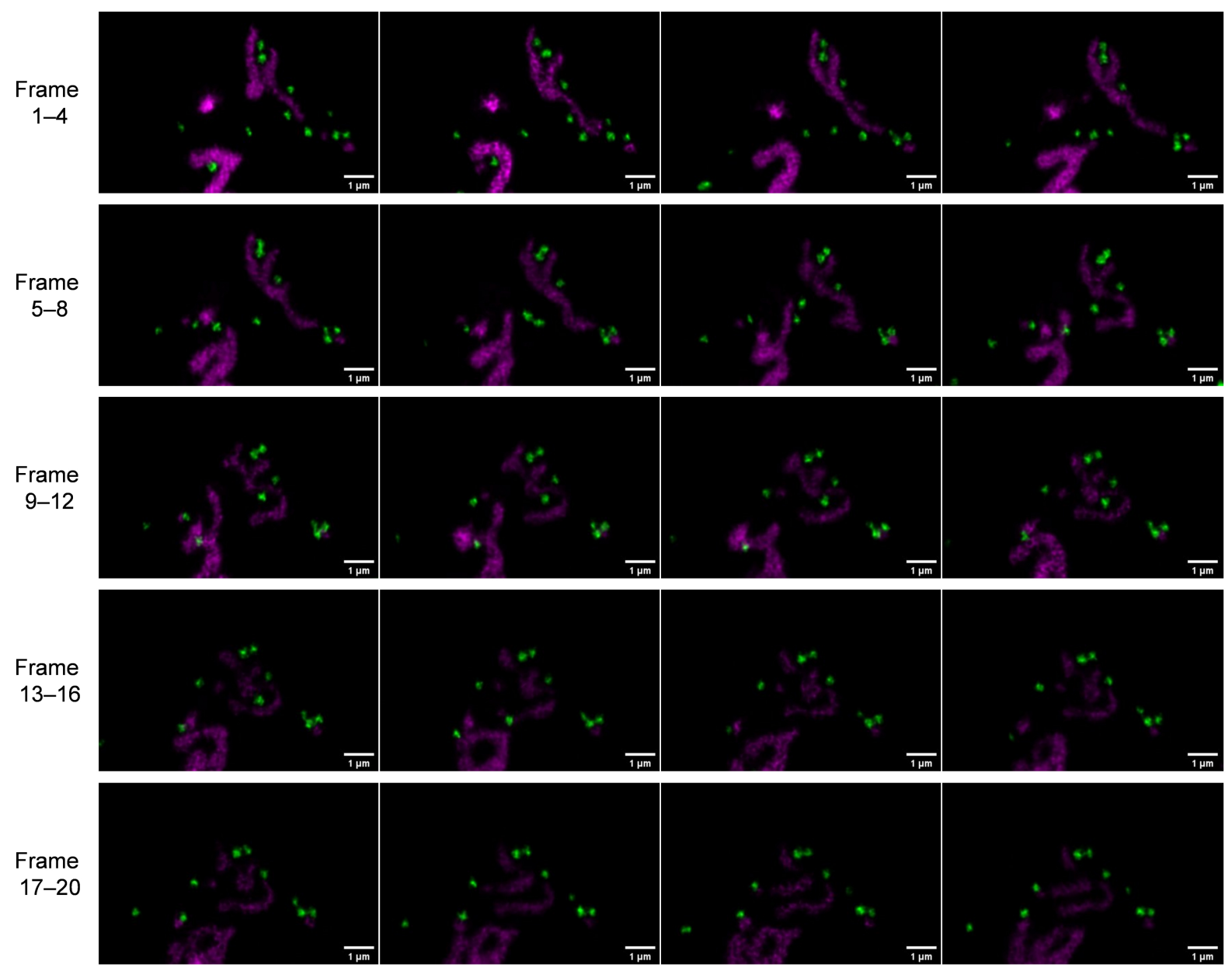

Figure S14. Two-color STED super-resolution imaging of living HeLa cells: the LDs (green pseudo color) and mitochondria (purple pseudo color) were labeled with Lipi-DSB and TMRM, respectively; scale bar: $1 \mu \mathrm{m}$; the STED images were recorded under two excitation lasers (470 nm for Lipi-DSB, $550 \mathrm{~nm}$ for TMRM) and one STED laser (660 nm CW-STED, $40 \mathrm{MW} \mathrm{cm}{ }^{-2}$ ). The fluorescence of mitochondria was photo-bleached quickly due to the insufficient photostability of TMRM. 
NMR spectra of synthesized molecules
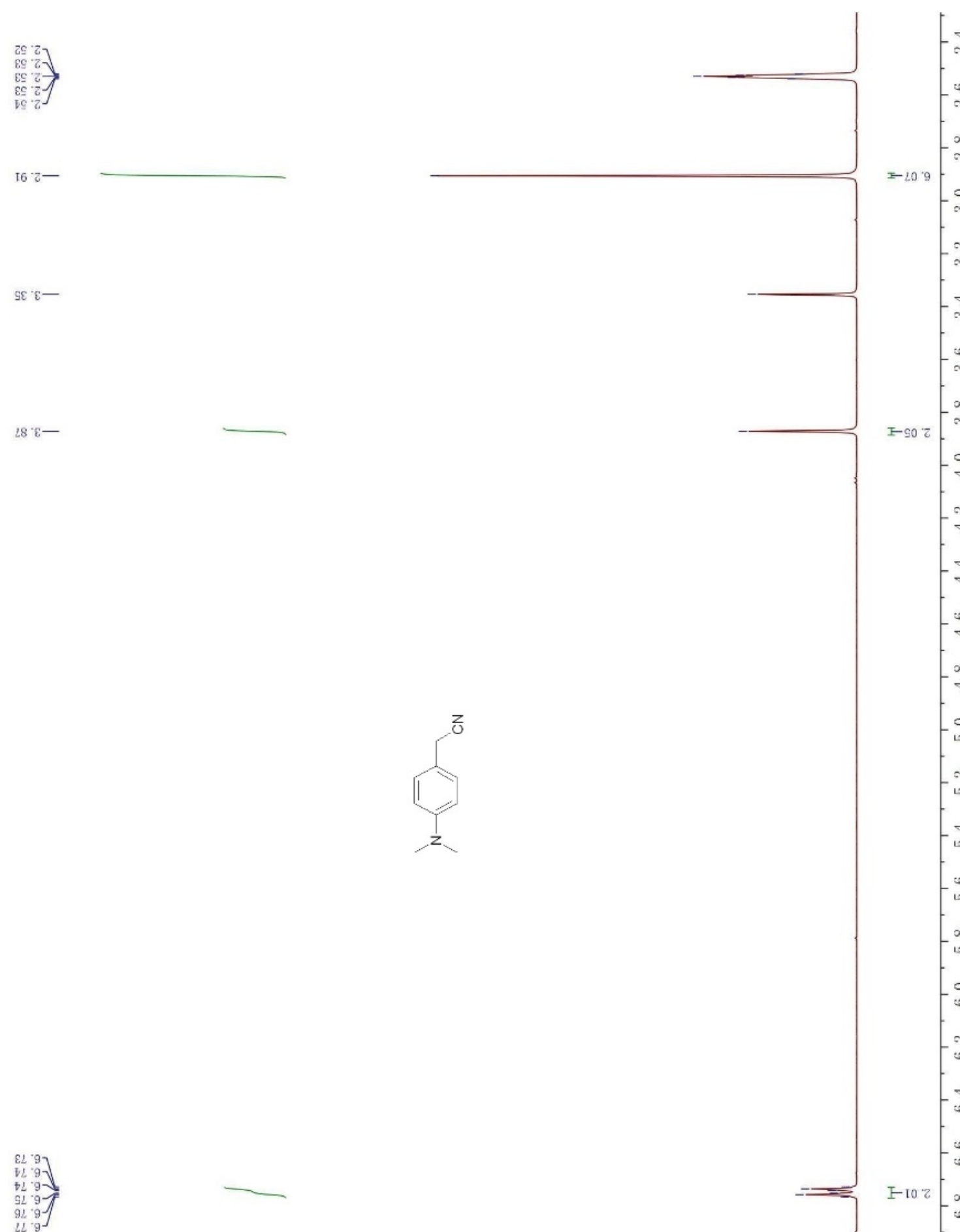

$\left.\begin{array}{lll}91 & 2 \\ 91 & 2 \\ 21 & 2 & 2 \\ 21 & 2\end{array}\right]$
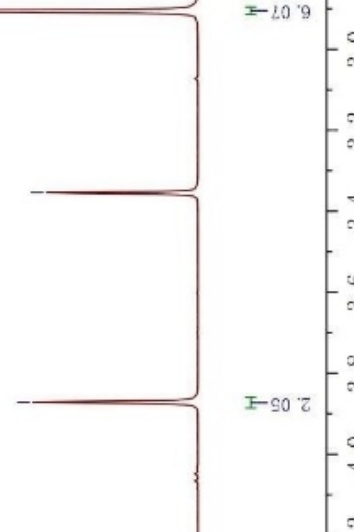


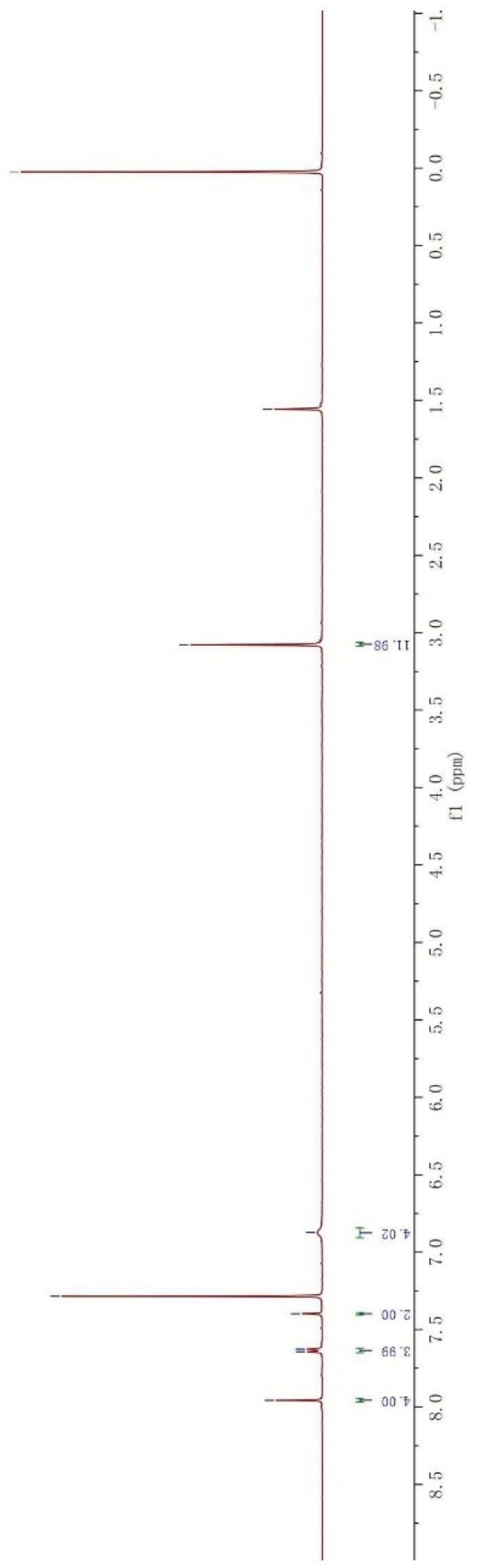

NMR-2. ${ }^{1} \mathrm{H}$ NMR spectrum of compound $1\left(500 \mathrm{MHz}, \mathrm{CDCl}_{3}\right)$. 


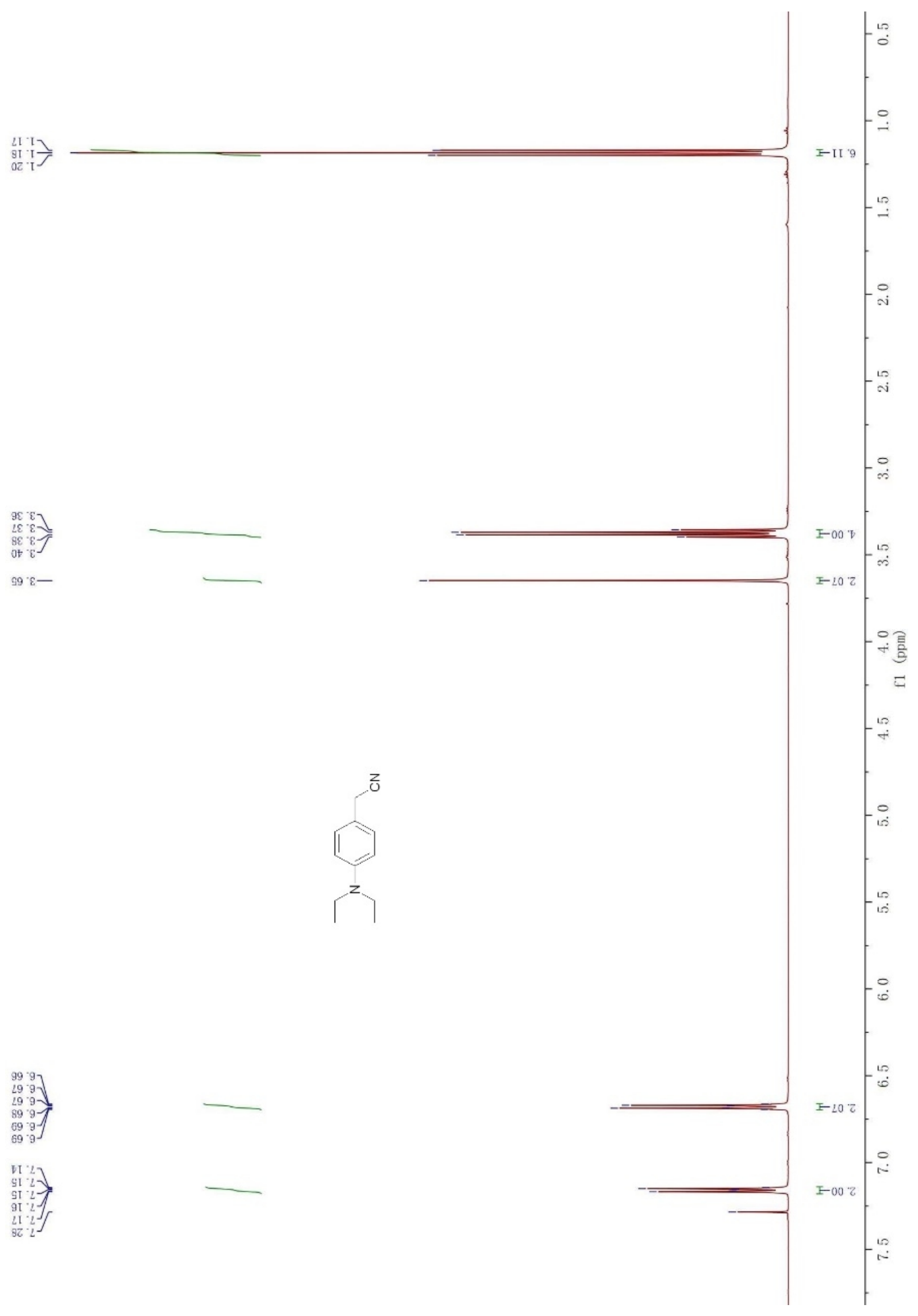

NMR-3. ${ }^{1} \mathrm{H}$ NMR spectrum of 2-(4-(diethylamino)phenyl)acetonitrile (500 $\left.\mathrm{MHz}, \mathrm{CDCl}_{3}\right)$. 


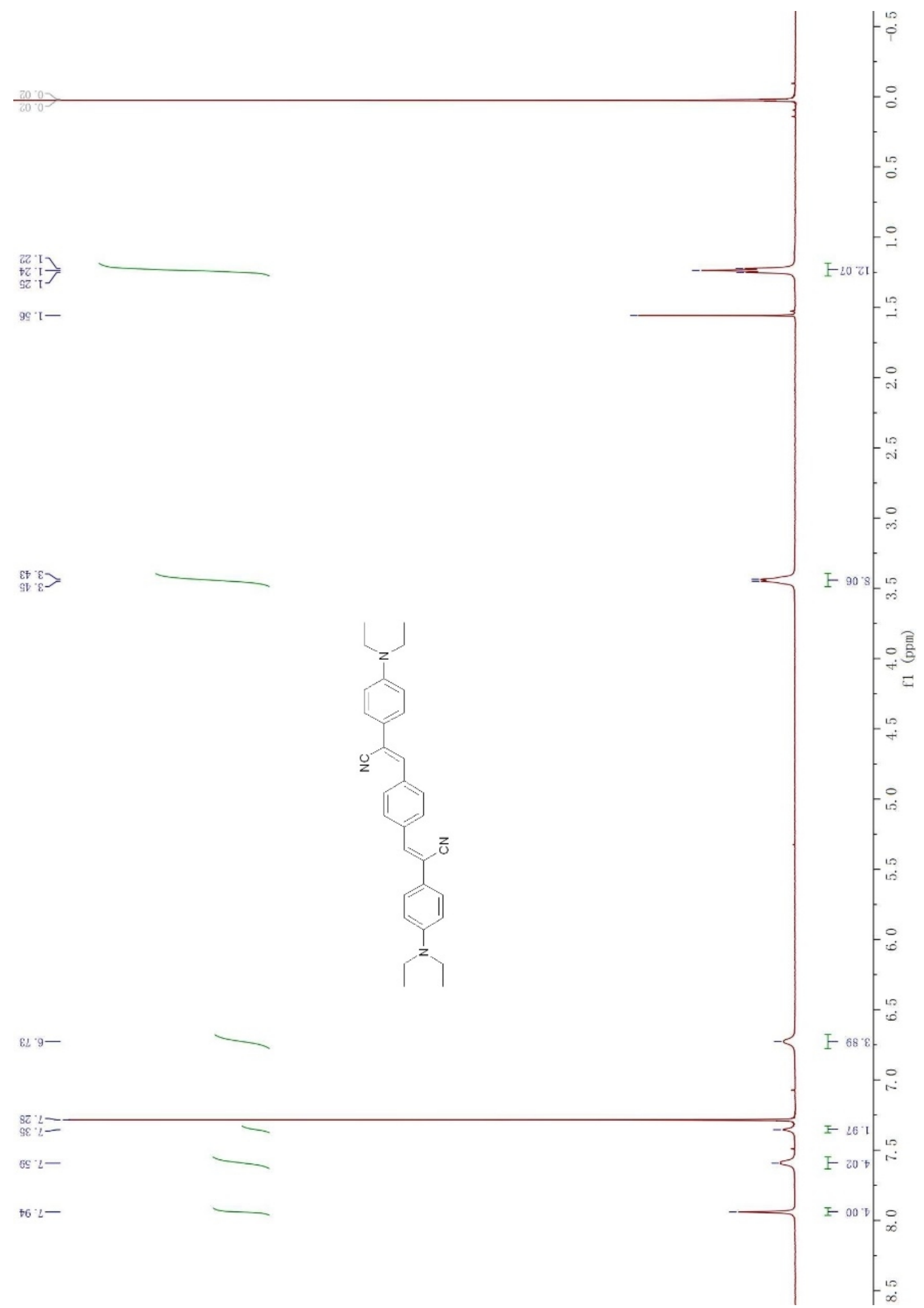

NMR-4. ${ }^{1} \mathrm{H}$ NMR spectrum of Lipi-DSB (500 MHz, $\left.\mathrm{CDCl}_{3}\right)$. 
$6 \mathrm{gI}-$

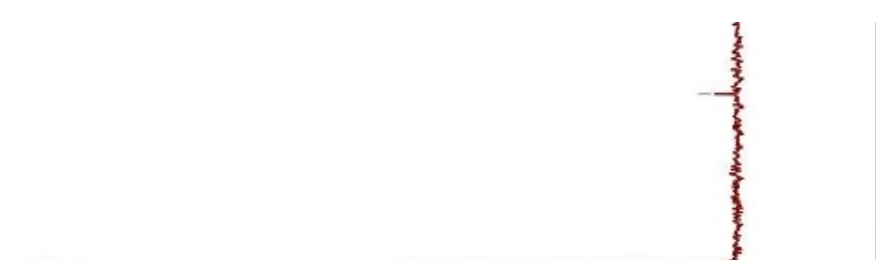

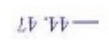
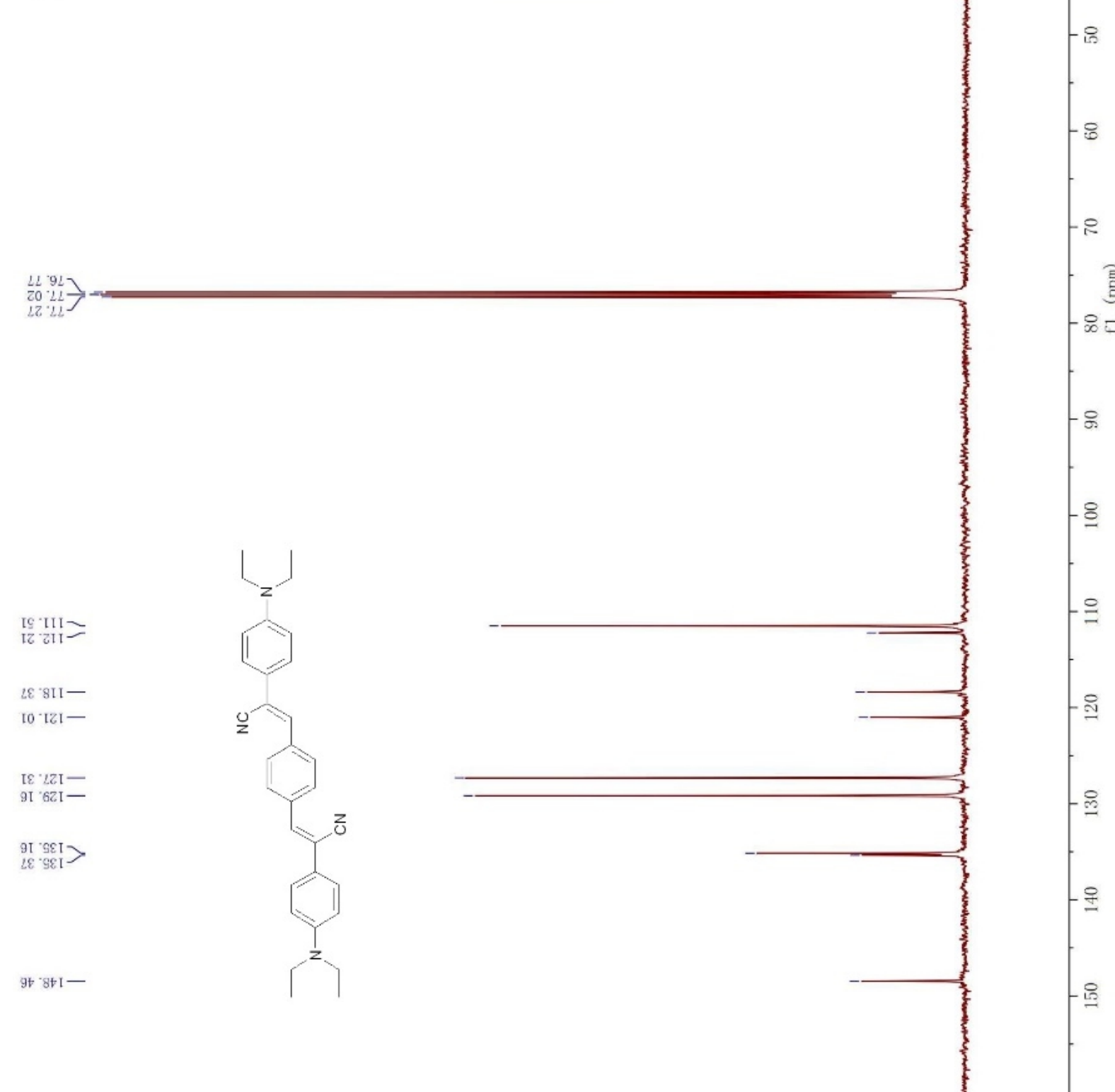

NMR-5. ${ }^{13} \mathrm{C}$ NMR spectrum of Lipi-DSB (126 MHz, $\left.\mathrm{CDCl}_{3}\right)$. 


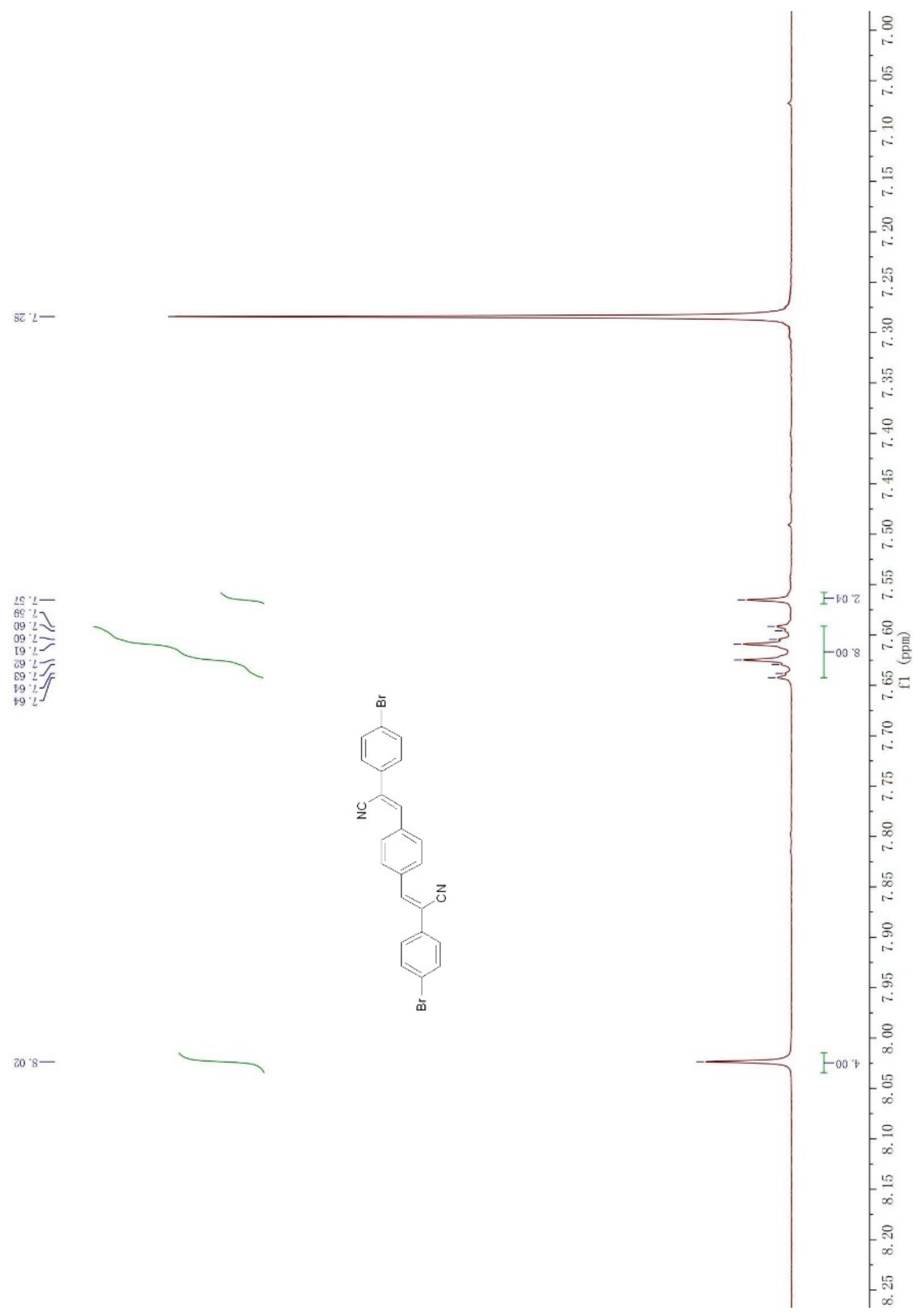

NMR-6. ${ }^{1} \mathrm{H}$ NMR spectrum of 1,4-bis[(1E)-2-(4-bromophenyl)ethenyl]benzene (500 MHz, $\left.\mathrm{CDCl}_{3}\right)$. 


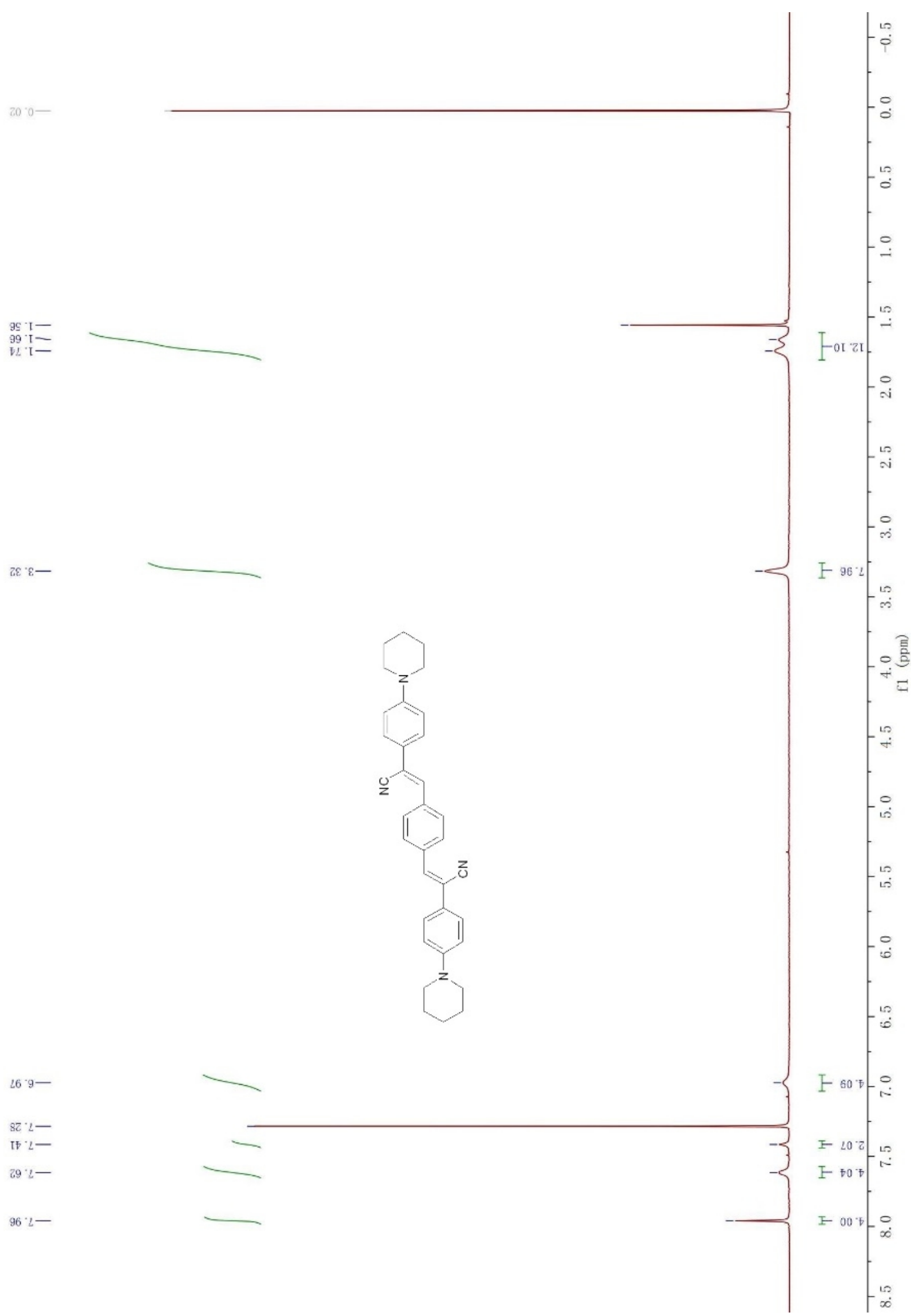

NMR-7. ${ }^{1} \mathrm{H}$ NMR spectrum of compound $2\left(500 \mathrm{MHz}, \mathrm{CDCl}_{3}\right)$. 